\title{
The History of the Russian Semelfactive: The Development of a Radial Category*
}

\author{
Tore Nesset, University of Tromsø
}

\begin{abstract}
:
This paper explores the history of suffixed semelfactive verbs in Russian, i.e., verbs like maxnut' 'wave once' with the -nu- suffix. It is argued that the semelfactive aktionsart is best analyzed as a radial category organized around a prototype with four properties: uniformity, instantaneousness, non-resultativity, and single occurrence, which are defined and discussed in the article. I go on to demonstrate that there is a small group of verbs denoting bodily acts that meet these criteria in the Old Church Slavonic texts, thus suggesting the existence of an embryonic version of the semelfactive aktionsart in Common Slavic. Although the cue validity of -nu- as a marker of semelfactivity remains stable, in Old Russian -nu- with semelfactive meaning is shown to spread to auditory verbs, optical verbs and verbs of physical movement, which are argued to constitute a radial category organized around prototypical bodily acts. This gradual expansion through the lexicon continues in Contemporary Standard Russian; in particular a number of semelfactive behavior verbs have emerged, although many of them are of low frequency.
\end{abstract}

\section{Introduction}

The Russian aspectual system is characterized by a division of labor between prefixes and suffixes. In general, perfective verbs are formed by the addition of prefixes with transparent spatial motivation, while imperfective verbs are formed by the addition of suffixes that lack clear spatial motivation. The only exception to this pattern is the so-called semelfactive aktionsart, i.e., verbs like maxnut' 'wave once' and stuknut' 'knock once'; these verbs are perfective although they are formed by means of a suffix with no obvious spatial motivation. ${ }^{1}$ In view of its exceptional status in the Russian aspectual system, the question arises as to how and when the Russian semelfactive aktionsart developed. The objective of the present study is to

\footnotetext{
* This article is based on research carried out at the Center for Advanced Study (CAS) at the Norwegian Academy of Science and Letters in Oslo. The support from CAS is gratefully acknowledged. I wish to thank all members of the Time is space research group at CAS, as well as the CLEAR (Cognitive Linguistics: Empirical Approaches to Russian) research group at the University of Troms $\varnothing$ for valuable input. I am responsible for remaining shortcomings.

${ }^{1}$ Some researchers, notably Isačenko (1960: 251-273) and Dickey and Janda (2009), consider verbs like sglupit' 'do one stupid thing' with the prefix $s$ - to be semelfactives. Verbs of this type will not be discussed in the present study, since they represent an independent and later development (Dickey and Janda 2009: 241). A general discussion of aktionsart and comparison with the other Russian aktionsarten (or "procedurals", Russian: sposoby dejstvija) is beyond the scope of the present study, since it is uncontroversial that semelfactives represent one of the Russian aktionsarten, i.e. certain semantic modifications of a base verb expressed by prefixes and/or suffixes (cf. Isačenko 1960: 216 and Zaliznjak and Šmelev 2000: 104 for discussion).
} 
shed light on this question based on an analysis of data from Old Church Slavonic (OCS), Old Russian, and Contemporary Standard Russian (CSR).

I suggest that the semelfactive aktionsart can be analyzed as a radial category structured around a prototype with four properties: uniformity, instantaneousness, non-resultativity, and single occurrence. The semelfactive aktionsart developed from an embryonic state reflected in the OCS texts, where a few unprefixed verbs describing bodily acts display semelfactive meaning. I argue that in Old Russian - nu- with semelfactive meaning spread to auditory verbs, optical verbs and verbs of physical movement, and that these verbs constitute a radial category structured around prototypical bodily acts. The expansion through the verbal lexicon is shown to continue in modern Russian, where a number of semelfactive verbs outside the subcategories attested in Old Russian have emerged. In addition to showing how the roots of the Russian semelfactive extend far back in the history of the Slavic languages, the present study shows that the radial category provides a valuable tool for analyzing of the development of morphological categories over time.

After a clarification of the notion of "semelfactive" in section 2, section 3 explores the embryonic stage in the Old Church Slavic texts, before we turn to the expansion of the semelfactive aktionsart in Old Russian and modern Russian in sections 4 and 5. The contribution of the article is summarized in section 6 .

\section{What is a semelfactive verb?}

Zaliznjak and Šmelev (2000: 118) define semelfactive verbs as "verbs that denote one 'quantum' of the activity described by the base verb". ${ }^{2}$ This definition raises the question of what a "quantum" is. While a "quantum" refers to one event ("one handwave" or "one knock") in a series of e.g. knocking or waving events, there are two properties that are relevant and require elaboration: uniformity and instantaneousness. Semelfactives are typically formed from activities that consist of repetitions of uniform subevents such as maxat' 'wave' and stučat' 'knock'; for all practical purposes each hand wave or knock in a series is identical. Activities that do not consist of repetitions of uniform subevents are less likely to form semelfactives. Thus, since rabotat' does not necessarily describe the repetition of identical operations, we do not expect a semelfactive to be formed from this verb. However, we are not dealing with a clear-cut division line; the fact that there are a few attestations of rabotnut' 'do one lick of work' in the Russian National Corpus shows that it is possible (albeit not very natural) to construe 'work' as an activity consisting of sufficiently uniform subevents to motivate the formation of a semelfactive. ${ }^{3}$ Examples like rabotnut'suggest that semelfactives are best described

\footnotetext{
2 “Glagoly, oboznačajuščie odin 'kvant' dejatel'nosti, opisyvaemoj isxodnym glagolom" (My translation. TN)

${ }^{3}$ Corpus search performed May 2012. As pointed out by an anonymous referee, with verbs like rabotnut', the function of -nu- to some extent resembles the function of the prefix po-, i.e., imposing boundaries on events that have no natural boundaries. However, while -nu-focuses on one unit of the process ("one lick of work"), po- denotes the unfolding of the process for a short time without dividing it into segments.
} 
as radial categories, i.e., networks of related subcategories organized around a prototype (Lakoff 1987). The radial category allows us to place events on a scale ranging from prototypical semelfactives with uniform subevents to peripheral category members such as rabotnut'. At the same time, the radial category does not force us to postulate an arbitrary cutoff point on this scale, which would arbitrarily separate semelfactive verbs from non-semelfactive verbs.

The property of instantaneousness also illustrates the advantages of radial categories organized around prototypes. Semelfactive verbs are normally instantaneous or punctual in the sense that the relevant "quantums" are conceptualized as having minimal duration. Therefore, verbs like maxnut' and stuknut' are compatible with momentaneous adverbials such as vdrug 'suddenly' and vnezapno 'suddenly' (cf. Smith 1997: 246). However, Isačenko (1982: 398) has shown that instantaneousness is not an absolute requirement, pointing out that kutnut' 'to go on a binge' may describe a drinking and partying subevent of considerable duration. However, there is no doubt that semelfactives typically are instantaneous. The radial category structured around a prototype enables us to accommodate peripheral examples such as rabotnut' and kutnut', while at the same time we capture the generalization that the properties of uniform and instantaneous "quantums" describe prototypical semelfactives.

A property of semelfactives that is not captured by Zaliznjak and Šmelev's (2000: 118) definition cited above is the fact that semelfactives tend to be nonresultative, in the sense that they do not culminate in a change of state (cf. e.g. Smith 1997: 246, Šatunovskij 2009: 66). In the case of maxnut', which is typical, we are dealing with cyclic subevents whereby the hand moves and then resumes its initial position, after which a new cycle of hand movements can begin. However, even though non-resultativity is characteristic of prototypical semelfactives, this is not a necessary condition for membership in the category, as illustrated by examples such as prygnut' 'jump once'. Admittedly, a sentence such as on prygnul 'he jumped' will most likely be interpreted as describing one jump up in the air and a landing on the same spot. This is non-resultative in the sense described above; the subject resumes his/her initial position and is ready to perform a new jump of the same type. However, in a sentence like the following the described event is resultative since it does indeed involve a change of state; the subject ends up on the other side of the fence after the jump: ${ }^{4}$

(1) On [...] prinužden byl prygnut' čerez zabor. [Turgenev 1859] 'He had to jump over the fence.'

Different scholars use "resultativity" and the closely related term "telicity" in different ways, but an in-depth discussion is beyond the scope of the present study (see, however, Dickey 2008: 331 for discussion of telicity). Suffice it to say that "resultativity" as defined above typically correlates with a low degree of affectedness of the participants; if an action does not culminate in a change of state

\footnotetext{
${ }^{4}$ All examples from Contemporary Standard Russian that are cited in the present study are excerpted from the Russian National Corpus available at www.ruscorpora.ru.
} 
the participants are not likely to be affected. However, this is not an all or nothing affair. By way of example, consider maxnut' 'wave', which is a typical non-resultative semelfactive verb insofar as the hand goes back to its initial position again after the waving gesture has been completed. Thus there is no change of state. However, when waving is used as a way of conveying a message, the addressee receives a message and in this sense is affected by the waving.

Before we leave the properties of prototypical semelfactives, it is worth pointing out that the term "semelfactive" (from Latin semel 'once' and facere 'make') is potentially misleading because it may create the impression that the relevant verbs cannot denote repeated actions. However, semelfactives are compatible with repeated actions, as shown by examples of the following type, where the cuckoo cries three times:

(2) - Kukuška, kukuška, skol'ko mne let žit'? - kriknul on ej. Kukuška kriknula tri raza i zamolkla. [Dombrovskij 1964]

'Cuckoo, cuckoo, how long am I going to live?-He shouted to her. The cuckoo cried out three times and then became silent.'

In (2) the reading involving repeated events is forced by the quantifier tri raza 'three times'. When no quantifier is present in the context, the normal reading of semelfactives is of one single event. Even if the subject is in the plural, as in the following example, the most likely interpretation is that the subjects performed one scream jointly:

(3) Ja snjala trubku, govorju: - Alle! A oni kriknuli: - Ty, tam! [Sadur 1989]

'I picked up the telephone saying -Hello! And they shouted: - You there!'

While most scholars agree that $-n u$ - is a marker of semelfactivity in Contemporary Standard Russian, there is often disagreement about the analysis of individual verbs. Is kosnut'sja 'touch', for instance, a semelfactive verb or just a (natural) perfective? Isačenko (1958/1984: 399) argues that it is a normal perfective, and most dictionaries seem to agree (cf. e.g. Evgen'eva (ed.) 1999 and Ožegov/Švedova 1999). However, Ušakov (1935-40/2008) classifies kosnut'sja as both a normal perfective and a semelfactive ("sov[eršennyj vid] i odnokr[atnyj sposob dejstvija] k kasat'sja"), and Berkov (2011) lists kosnut'sja as a semelfactive verb in the entry for the imperfective kasat'sja 'touch'. The question is not trivial empirically or theoretically.

On the one hand, verbs like kosnut'sja occur in the contexts that are prototypical for semelfactives. In the following sentence, which includes the momentaneous adverbial $v$ drug 'suddenly', we are dealing with an instantaneous act whereby an arm reaches out, touches the face and then moves away from the face again:

(4) On uže načal zasypat', kak vdrug ego lica kosnulas' detskaja ruka. [Simonov 1955-1959] 
'He was already beginning to fall asleep when suddenly the hand of a child touched his face.'

On the other hand, kosnut'sja is also attested in contexts with properties that seem incompatible with semelfactives, such as duration. While adverbials of duration like nenadolgo 'for a short while' appear to be incompatible with prototypical semelfactives like kašljanut' 'cough', kosnut'sja is attested in combination with nenadolgo in examples of the following type, where the event cannot be conceptualized as instantaneous:

(5) Nužno, čtoby každaja kletka «zaxvatyvala» na poverxnosti solnečnyj luč, prežde čem nenadolgo kosnut'sja dna, propustiv k solncu drugie kletki. [«Texnika - molodeži», 1977]

"It is necessary for each cell to "capture" a ray of sunlight on the surface before it briefly touches the bottom, allowing other cells access to the sun.'

In addition, kosnut'sja differs from maxnut' and stuknut' in that the corresponding imperfective verb kasat'sja can denote a state rather than an activity consisting of a series of uniform and instantaneous subevents.

The question now arises as to whether a stative base verb and compatibility with adverbials of duration force us to conclude that kosnut'sja is not a semelfactive. As we have seen, the criteria discussed above do not enable us to draw a clear-cut boundary between semelfactives and other perfective verbs. Moreover, we have seen that even relatively uncontroversial examples of semelfactive verbs such as prygnut' 'jump once' (cf. e.g. Švedova and Ožegov 2001, Evgen'eva 1999) are attested in contexts that are normally considered to be at variance with the semelfactive aktionsart (e.g. prygnut' čerez zabor 'jump over the fence' in (1) above). Rather than trying to decide whether kosnut'sja is a semelfactive in Contemporary Standard Russian (CSR), I argue that this is not the right question to ask. Instead of trying to draw a clear-cut boundary between semelfactives and other perfective verbs, what we need is a linguistic framework that is flexible enough to capture the differences and similarities along the continuum from prototypical semelfactives via peripheral semelfactives to other perfective verbs, thus assessing the degree of prototypicality rather than the presence or absence of a distinctive feature, such as [+semelfactive]. Cognitive linguistics offers such a framework by means of its emphasis on radial categories organized around prototypes. In sum, I propose that the semelfactive aktionsart represents a radial category where the prototypical subcategory posits the properties uniformity, instantaneousness, non-resultativity and single occurrence, but where deviations from one or more features are attested in peripheral subcategories. This conception of the semelfactive aktionsart will inform the discussion of its origin and historical development in Russian, to which we turn in the following sections of this article.

\section{Old Church Slavonic: the embryonic stage}

In order to trace the origin and early development of the Russian semelfactive aktionsart, we must ask if there existed verbs in Common Slavic with prototypical 
semelfactive meaning, and if this meaning was associated with the nasal suffix that developed into -nu- in Contemporary Standard Russian. In the following, I will show that there were a handful of such verbs. Although it is hard to determine to what extent the nasal suffix was grammaticalized as a morphological marker of the semelfactive aktionsart, it seems safe to conclude that at least an embryonic version of the semelfactive aktionsart existed already in Late Common Slavic.

\subsection{Data}

The fact that verbs with semelfactive meaning are attested in South, West and East Slavic languages suggests that the semelfactive aktionsart existed already in Common Slavic. However, in order to present a more precise account of the meanings of the relevant verbs it is necessary to examine how they are used in context. For this reason, in the following we turn to the OCS text canon. Although this text corpus does not reflect the speech of any one speech community at any point in history, these texts nevertheless shed light on the situation in Late Common Slavic.

The possible existence of a semelfactive aktionsart in the OCS texts is an open question. Most grammars (e.g. Diels 1961 and Lunt 2001) do not discuss the aspectual properties of the relevant verbs at all, and Dostál's (1954) classic study of aspect in OCS only classifies the verbs in question as perfective without exploring aktionsarten. Maslov (1961/2004: 462, see also Bertinetto and Lentovskaya 2011) asserts that there was a semelfactive aktionsart (Russian: "mgnovenno-odnoaktnyj (semel'faktivnyj) sposob dejstvija") in OCS, but does not discuss the use of the relevant verbs in detail.

Nesset (to appear) has set up a database using data from Sadnik and Aitzetmüller (1955) and Aitzetmüller (1977) and reports that the OCS texts contain 78 verbs with the nasal suffix -no- (the cognate of Russian -nu-). However, the majority of the attested verbs are prefixed. Since what we are interested in in the present study is the relationship between semelfactive meaning and the nasal suffix, the semantic contribution of prefixes represent a confounding factor, and prefixed verbs will therefore not be discussed in the following. Furthermore, many unprefixed verbs with the nasal suffix are imperfective and have meanings that are not relevant for the semelfactive aktionsart-a fact we will return to below. At least if we take a conservative definition of the semelfactive aktionsart as our point of departure, the list of likely suspects for semelfactive verbs is quite short, as shown in Table 1, which contains all 14 unprefixed verbs in -no- that are classified as perfective in Cejtlin, Večerka and Blagova (1999). ${ }^{5}$

\footnotetext{
5 I have not included pomanoti 'beckon, wave at, nod to' and pomęnoti 'remember' in the list, since pomay be analyzed as a prefix. In the case of užasnoti sę 'be astonished' we are possibly dealing with the prefix $u$-, and this verb is therefore not on the list. Gybnoti (4) 'die' is excluded since it is classified as biaspectual, i.e., used as both a perfective and imperfective verb. In addition to the verbs in Table 1, Dostál (1954: 71) lists dzxnoti 'breathe', kliknoti 'cry out, exult', and krъknoti 'squeak' as perfective. However, I have not included the first two in Table 1, since according to Aitzetmüller (1977) they are not attested as unprefixed verbs. Since krzknoti has only one attestation (in Codex Suprasliensis, cf. Aitzetmüller 1977: 232), it is difficult to assess its aspectual properties with certainty.
} 


\begin{tabular}{llr} 
Verb & Gloss & Number of attestations: \\
\hline drbznqti & 'take courage, be bold' & 31 \\
goneznqti & 'avoid' & 10 \\
minqti & 'pass by' & 10 \\
dvignoti & 'move' & 26 \\
mrbknqti & 'get dark' & 8 \\
vyknqti & 'learn, get used to' & 5 \\
kanqti & 'drip' & 1 \\
dunqti & 'blow' & 4 \\
plinqti/pljunqti & 'spit' & 14 \\
zinqti & 'yawn' & 2 \\
kosnqti & 'touch' & 43 \\
rinqti & 'push' & 1 \\
tlbknqti & 'knock' & 8 \\
tzknqti & 'strike, pierce, wound' & 2 \\
Total & & 165
\end{tabular}

Table 1: All unprefixed perfective OCS verbs with the -no- suffix

Are there any verbs in Table 1 that display all the properties characteristic of prototypical semelfactives, i.e., uniformity, instantaneousness, non-resultativity and single occurrence? Drbznoti 'take courage, be bold', goneznoti 'avoid' and minoti 'pass by' do not correspond to activities that consist of uniform subevents. Some of the verbs in Table 1 are clearly resultative in that they denote a goal-oriented process that culminates in a change of state. This applies to dvignoti 'move', mrbknoti 'get dark' and vyknoti 'learn, get used to'. When these verbs are set aside, we are left with eight verbs. With the exception of kanoti 'drip', which is attested only once, the remaining verbs are bodily acts, i.e., volitional actions performed by an agentive subject who moves a body part in order to carry out the action. ${ }^{6}$ The bodily acts in Table 1 fall into two semantic groups, according to which body part is central. On the one hand, we have the "mouth-based" acts dunoti "blow', plinoti/pljunoti 'spit' and zinqti 'yawn'. The other group consists of "hand-based" acts, namely kosnoti 'touch', rinoti 'push', tlbknoti 'knock' and tъknoti 'strike, pierce, wound'. We explore mouth-based acts in section 3.2 and turn to hand-based acts in 3.3 .

\subsection{Mouth-based bodily acts}

Mouth-based acts such as spitting, blowing and yawning are all activities that consist of uniform subevents that can easily be construed as instantaneous. Furthermore, these verbs do not lead to a change of state; when one act of spitting, blowing or yawning has been performed, the agent is ready to perform another identical act. In other words, the mouth-based bodily acts are excellent candidates

\footnotetext{
${ }^{6}$ Since we have only a single attestation of kanoti 'drip' it is difficult to pinpoint the exact meaning of this verb. However, the attested example is about a meteorological phenomenon, which suggests that the verb does not belong together with the bodily acts. It is worth mentioning that Dostál (1954: 71) did not include kanoti in his list of perfective verbs.
} 
for semelfactive verbs. However, in order to settle the issue we need to go beyond the lexical meaning and explore how such verbs are used.

For this purpose, I propose considering the spitting verbs in some detail. We have more attestations of plineti/pljunoti than dunoti and zinoti, and we are also in a position to compare plinoti/pljunoti to the unprefixed imperfective activity verb plbvatiand the perfective prefixed derivations zaplovati and oplbvati, which are also attested. As shown in Table 2, verbs with the root pli-/plju- 'spit' occur in six episodes in the OCS translations of the New Testament. ${ }^{7}$ Episodes A, B and C involve aorists or past active participles of plinoti. All these episodes describe how Jesus heals blind and deaf/mute men. John 9.6 is illustrative: ${ }^{8}$

(6) Si rekъ pling na zemljo i sъtvori brenie otъ plinoveniě i pomaza emu oči brъnьemb.

'Having said this, he spat on the ground, made some mud with the saliva, and put it on the man's eyes.'

Characteristic of these episodes is the fact that the spitting event is embedded in a sequence of consecutive events that are performed by a single agent. The verb is used intransitively (in combination with a PP, rather than an object NP). Although the spitting is a means to achieve a goal, the focus is not on a change of state caused by the spitting itself; we are interested in what happens to the deaf and mute man, but not what happens to the ground after it has been spat on. In other words, resultativity is not in focus.

\begin{tabular}{|c|c|c|c|c|c|}
\hline Episode & Bible ref & Form & Features & Prefix & $-n q$ \\
\hline $\begin{array}{l}\text { A. The Healing of a Deaf and } \\
\text { Mute Man }\end{array}$ & Mark 7.33 & plingvъ & $\begin{array}{l}\text { past act part } \\
\text { masc sg nom }\end{array}$ & no & yes \\
\hline $\begin{array}{l}\text { B. The Healing of a Blind Man } \\
\text { at Bethsaida }\end{array}$ & Mark 8.23 & pling & 3 sg aorist & no & yes \\
\hline $\begin{array}{l}\text { C. Jesus Heals a Man Born } \\
\text { Blind }\end{array}$ & John 9.6 & pling & 3 sg aorist & no & yes \\
\hline $\begin{array}{l}\text { D. Jesus Again Predicts His } \\
\text { Death }\end{array}$ & $\begin{array}{l}\text { Mark } 10.34 \\
\text { Luke } 18.32\end{array}$ & $\begin{array}{l}\text { opljujotz } \\
\text { zapljujotz }\end{array}$ & 3 pl non-past & yes & no \\
\hline E. Jesus before the Sanhedrin & $\begin{array}{l}\text { Matt } 26.67 \\
\text { Mark } 14.65\end{array}$ & $\begin{array}{l}\text { zaplьvaša } \\
\text { načasja plıvati }\end{array}$ & $\begin{array}{l}3 \mathrm{pl} \text { aorist } \\
3 \mathrm{pl} \text { aux }+\inf \end{array}$ & $\begin{array}{l}\text { yes } \\
\text { no }\end{array}$ & $\begin{array}{l}\text { no } \\
\text { no }\end{array}$ \\
\hline F. The Soldiers Mock Jesus & Matt 27.30 & plingvъše & $\begin{array}{l}\text { past act part } \\
\text { masc pl nom }\end{array}$ & no & yes \\
\hline & Mark 15.19 & plbvaaxo & 3 pl imperfect & no & no \\
\hline
\end{tabular}

Table 2: Verbs of spitting in OCS translations of the New Testament

\footnotetext{
${ }^{7}$ I treat the two stories about Jesus healing blind men as different "episodes", since they are linguistically quite different, and because the evangelists place them in different parts of the Holy Land (Bethsaida in Galilee and the Pool of Siloam near Jerusalem, respectively). I am indebted to my friend cand. theol. Simen Aalvik Simensen for input on this issue.

8 This is the version from Codex Marianus, cited from the PROIEL electronic corpus available at http://foni.uio.no:3000/. The same form, the 3 sg aorist pling, is also used in Codex Zographensis and Codex Assemanianus, the only other attestations of John 9.6 in OCS.
} 
Episodes D and E in Table 2 have prefixed inflected verbs (either oplbvati/zaplbvati or the auxiliary verb načati 'begin'). All these episodes describe harassments of Jesus. By way of example, consider Matthew 26.67: ${ }^{9}$

(7) Tъgda zaplıvaša lice ego i pakosti emu děašę. Ovi že za lanito udarišę. 'Then they spat in his face and struck him with their fists. Others slapped him.'

In (6) we are dealing with a series of consecutive events, but otherwise the context of the prefixed verb in (7) is quite different from (6). Rather than a single spitting event, (7) describes multiple events, insofar as there are several agents (the soldiers) and each agent may perform one or several acts of spitting. Furthermore, the verb is used transitively. This suggests that the event is resultative since the object (the face of Jesus) is directly affected by the spitting. The face gets covered with saliva and as a result Jesus is humiliated. The act is resultative in the sense that Jesus undergoes a change of state, and the narrative is about what happens to Jesus.

Comparison of (6) and (7) suggests that the unprefixed verb with -no- is used about single acts performed by one agent, and that the verb is intransitive and nonresultative. Prefixed verbs, on the other hand, seem to be used about multiple acts carried out by several agents, and the prefixed verbs are transitive and resultative. This squares well with an analysis of the unprefixed verb with - $n g$ - as semelfactive, and the prefixed verbs as non-semelfactive perfectives. However, episode F in Table 2 complicates the picture. Here again Jesus is being humiliated by soldiers. This is described slightly differently in Mark 15.19 and Matthew 27.30. Mark describes several parallel events that taken together constitute the "macroevent" of humiliating Jesus. ${ }^{10}$

(8) I biěxo i trъstbjo po glavě i plbvaaxo na nь. I prěgybajošte kolěna klaněaxọ sę emu.

'Again and again they struck him on the head with a staff and spat on him. Falling on their knees, they paid homage to him.'

The use of the imperfective activity verb plbvati in the imperfect past tense form emphasizes that we are dealing with parallel and possibly repeated events that are not sequentially ordered.

In Matthew 27.29-30, the same episode is described as follows: ${ }^{11}$

\footnotetext{
${ }_{9}^{9}$ This is the version in Codex Marianus. Codex Zographensis, Codex Assemanianus, and Savvina kniga have the same form. For the purposes of this study, Codex Marianus is cited from the PROIEL corpus (http://foni.uio.no:3000/), while Codex Zographensis, Codex Assemanianus, and Savvina kniga are cited from Jaap Kamphuis' parallel corpus of OCS gospel texts (http://www.jaapkamphuis.nl/index.php/parallel-corpus1)

${ }^{10}$ The example is from Codex Marianus. The same form is attested in Codex Zographensis, Codex Assemanianus and Savvina kniga.

${ }^{11}$ Citation from Codex Marianus. The same participle is attested in Codex Zographensis; Codex Assemanianus and Savvina kniga have the variant pljunovbše, i.e., the same grammatical form, but a different variant of the stem.
} 
(9) I sъpletъše věnecъ otъ trъniě vъzložišę na glavǫ ego i trıstı vb desnico ego i poklonıše sę na kolěnu prědъ nimb roqgaaxǫ sę emu gljǫšte radui sę csrju ijudiskъ i plinqvъše na nь prijęsę trıstı i biěxo i po glavě.

'And then they twisted together a crown of thorns and set it on his head and put a staff in his right hand and knelt in front of him and mocked him, saying "Hail, king of the Jews!" They spat on him, and took the staff and struck him on the head.'

Here the episode is presented as a sequence, in which the spitting came first and was followed by the soldiers picking up the staff and starting to hit Jesus. The OCS text relates the spitting to the picking up of the staff, rather than the hitting per se. Since picking up the staff is an accomplishment, which lends itself to sequential ordering, it makes sense to conceptualize the spitting event as a bounded event too. This suggests that the unprefixed $n q$-verb is compatible with multiple spitting events performed by several subjects, as long as they constitute one "macroevent" that is sequentially ordered with respect to other events. Resultativity is less prominent; the verb is intransitive, and the spitting is just one of several subevents in the "macroevent" of mocking. ${ }^{12}$

Are examples like (9) at variance with an analysis of plinoti/pljunoti as a semelfactive verb? The answer is clearly "no". While such examples are not prototypical for semelfactives, we have parallel uses of this kind in Contemporary Standard Russian, as shown in section 2 above. If one would use examples like (9) as counterarguments against a semelfactive aktionsart in OCS, one would be forced to give up the assumption of a semelfactive aktionsart in Contemporary Standard Russian as well-a move that hardly any analyst would be ready to make.

Before we leave the mouth-based acts, let us briefly consider the remaining two verbs in this group, namely dunoti 'blow' and zinoti 'yawn'. In John 20.22, dunoti is used as a prototypical semelfactive, insofar as Jesus performs a single act of breathing: ${ }^{13}$

(10) Reče imъ ís. paky. mirъ vamъ. ěkože posъla mę otъcъ i azъ sъlǫ vy. I se rekъ dunu i ğla imъ. priiměte dxa șta.

'Again Jesus said, "Peace be with you! As the Father has sent me, I am sending you." And with that he breathed [on them] and said, "Receive the Holy Spirit."

When breathing is resultative and leads to a change of state, prefixed verbs tend to be used. By way of illustration, consider the use of vъdunoti in Codex Suprasliensis (cited after Severjanov (ed.) 1904/1956: 22,3):

(11) [...] iže vъdujo namъ dxa staago.

'[...] who breathes the Holy Spirit into us.'

\footnotetext{
${ }^{12}$ As pointed out by an anonymous referee, one reason why plingti is used in (9) although the context for a semelfactive verb is not prototypical, is that the imperfective plbvati 'spit' cannot do the job, since it cannot occur in the aorist with the meaning "bounded activity" ("spit for a while").

13 The example, which is cited from Codex Marianus, is also attested in Codex Assemanianus. Marianus has the aorist dunu, while Assemanianus has duno.
} 
Whereas in (10) the breathing is described as a separate event from the receiving of the Holy Spirit, in (11) these two events are "conflated"; the Holy Spirit moves into the dative object through the breathing, and the breathing therefore entails a change of state in the dative object.

The last mouth-based verb, zinoti, is only attested twice, and both attestations are from Codex Suprasliensis. Here is one of the examples (cited after Severjanov (ed.) 1904/1956: 487,21):

(12) Zino adъ usty svoimi.

'Hell opened its mouth.'

Although it is difficult to pinpoint the exact nature of this event, it seems likely that we are dealing with the sudden opening of the mouth of hell on one single occasion. This is compatible with the interpretation of zinoti as a semelfactive verb.

\subsection{Hand-based bodily acts}

For hand-based bodily acts, kosnoti se 'touch' lends itself to critical scrutiny, since it is well attested and competes with the prefixed perfective prikosnoti se 'touch'. Particularly revealing is the story about the woman who touched the edge of Jesus' cloak and was healed from the bleeding she had suffered from for twelve years. Not only does this story contain several instances of 'touch', it is told by three different evangelists and is attested in four different OCS manuscripts. Table 3, which provides an overview of the distribution of kosnoti sę and prikosnoti se, shows that while the prefixed verb is the most frequent option, the unprefixed verb is also attested. It is worth pointing out that both verbs occur in identical contexts. In the first sentence in the story, where the woman "came up behind him and touched the edge of his cloak" we have a prefixed verb in Mark 5.27, while Matthew 9.20 and Luke 8.44 display variation. It is not the case that a certain OCS manuscript prefers either variant. In Matthew 9.20, the unprefixed verb is found in Savvina kniga, while the other sources have a prefixed verb. In Luke 8.44, we observe the opposite pattern; here it is Savvina kniga that displays the prefixed variant, while the other manuscripts present the unprefixed verb. This suggests that the two verbs must have had (nearly) identical meanings.

\begin{tabular}{|c|c|c|c|c|c|}
\hline Evangelist & English & Marianus & Zographensis & Asseman. & Savvina kniga \\
\hline Matt 9.20f. & $\begin{array}{l}\text { Just then a woman [...] } \\
\text { came up behind him } \\
\text { and touched the edge } \\
\text { of his cloak }\end{array}$ & prikosno sę & not attested & prikosno sę & kosno sę \\
\hline Matt 9.20f. & $\begin{array}{l}\text { "If I only touch his } \\
\text { cloak, I will be healed." }\end{array}$ & prikosno sę & not attested & prikosno sę & kosno sę \\
\hline $\begin{array}{l}\text { Mark } \\
5.27 \mathrm{ff}\end{array}$ & $\begin{array}{l}\text { She came up behind } \\
\text { him in the crowd and } \\
\text { touched his cloak }\end{array}$ & prikosno sę & prikosno sę & prikosno sę & prikosno sę \\
\hline $\begin{array}{l}\text { Mark } \\
5.27 \mathrm{ff} .\end{array}$ & $\begin{array}{l}\text { If I just touch his } \\
\text { clothes, I will be } \\
\text { healed }\end{array}$ & prikosno sę & prikosno sę & prikosno sę & prikosno sę \\
\hline Mark & "Who touched my & prikosno sę & prikosno sę & prikosno sę & prikosno sę \\
\hline
\end{tabular}




\begin{tabular}{|c|c|c|c|c|c|}
\hline $5.27 \mathrm{ff}$. & clothes?" & & & & \\
\hline $\begin{array}{l}\text { Mark } \\
5.27 \mathrm{ff} .\end{array}$ & $\begin{array}{l}\text { "And yet you can ask, } \\
\text { 'Who touched me?"” }\end{array}$ & prikosng sę & prikosno sę & prikosno sę & prikosng sę \\
\hline $\begin{array}{l}\text { Luke } \\
8.44 \mathrm{ff} .\end{array}$ & $\begin{array}{l}\text { She came up behind } \\
\text { him and touched the } \\
\text { edge of his cloak }\end{array}$ & kosno sę & kosno sę & kosno sę & prikosng sę \\
\hline $\begin{array}{l}\text { Luke } \\
8.44 \mathrm{ff} .\end{array}$ & "Who touched me?" & kosnǫvy sę & kosnoqvy sę & prikosno sę & prikosnovysę \\
\hline $\begin{array}{l}\text { Luke } \\
8.44 \mathrm{ff} .\end{array}$ & Someone touched me & kosnǫvy sę & kosnǫvy sę & prikosno sę & prikosno sę \\
\hline $\begin{array}{l}\text { Luke } \\
8.44 \mathrm{ff} \text {. }\end{array}$ & $\begin{array}{l}\text { She told why she had } \\
\text { touched him }\end{array}$ & prikosno sę & prikosno[vy] sę & prikosno sę & prikosno sę \\
\hline
\end{tabular}

Table 3: The woman who had been subject to bleeding-kosnoti sę (boldfaced) vs. prikosnoti $s e$ (italicized)

In addition to illustrating the free variation between kosnoti sę and prikosnoti sę, the data in Table 3 also indicates that kosnoti sę is used about sequentially ordered events that are conceived of as instantaneous and non-resultative. The woman touching the edge of Jesus' cloak is most likely instantaneous, and although the episode as a whole has tremendous consequences for the woman's health, these are not the result the touching event per se, but a result of the power going out from Jesus. In section 2, I argued that the modern Russian verb kosnut'sja is a semelfactive verb (albeit not a prototypical one). Since the situation in OCS and Contemporary Standard Russian seem quite parallel, I conclude that kosnoti was a (somewhat non-prototypical) semelfactive verb in OCS. ${ }^{14}$

The remaining hand-based bodily acts are less well attested, and a thorough discussion of their meaning and use is therefore not feasible. The following example from Codex Marianus (Luke 12.36) illustrates the use of tlъknoti 'knock':

(13) I vy podobьni člkomь čajǫ̌temь gá svoego kogda vъzvratitъ sę otъ brakъ. da prišedъšju i tlъknǫvъšju abie otvrъzǫtъ sę emu.

'And you like men waiting for their master to return from a wedding banquet, so that when he comes and knocks they can immediately open the door for him.'

\footnotetext{
${ }^{14}$ Although all the examples cited above involve the reflexive clitic $s e$, it is worth pointing out that unprefixed kosnoti is attested without the clitic. According to Eckhoff (2010), the non-reflexive verb is only attested in the (extraordinary) situations where Jesus heals someone by touching. Such cases may be considered "resultative" since the touching leads to a radical change of state in the affected persons. The existence of such "resultative" examples provides yet another argument in favor of a prototype-based approach to the semelfactive aktionsart, insofar as it illustrates that kosnoti is not a prototypical semelfactive verb. At the same time it is interesting to note that the non-resultative type with the clitic is much more frequent (Eckhoff counts 26 examples with the reflexive clitic, and only 8 without), and that it is the version with the clitic that has survived in modern Russian where only kosnut'sja, but not *kosnut' is attested. This suggests that the meaning of the reflexive clitic ("nonresultativity") is more compatible with the meaning of the semelfactive aktionsart than the "resultative" meaning of the cliticized verb. While the relationship between the semelfactive suffix and the -sja postfix is an interesting topic for future research, it is beyond the scope of the present article.
} 
The adverbial abie 'immediately' suggests that this is a sudden knocking event that is compatible with analyzing tlrknoti as a semelfactive verb. Likewise, the following example from Codex Suprasliensis (Severjanov 1904/1956: 162,25) with trknoti 'strike' is compatible with semelfactive meaning, since Alexander was hit once, as is evident from the context:

(14) [...] pristrašenъ byvъ. tъkno alexandra.

'Having been scared, he struck at Alexander.'

The last verb that may possibly be classified as a bodily act is rineti, which Lunt (1969) glosses as 'push'. However, it is only attested in the following example from Codex Suprasliensis (Severjanov 1904/1956: 535,19) where it co-occurs with the reflexive clitic sę and appears to signal the sudden onset of throwing insults and fighting:

(15) To slyšavъše otъ svjatogo moža grada togo mǫži rinq̨šę sę na ukorizny i bьjenьja.

'Having heard this the men of the town set to throwing insults and fighting.'

In order to clarify the lexical meaning of rinoti, we are forced to consider prefixed verbs like nizъringti 'throw down', which occurs in Luke 4.29:15

(16) I vъstavъše izgъnašę i vonъ iz grada \ věsę i do vrъxu gory na neiže gradъ ixъ sъzъdanъ běaše da bọ i nizъrinọli.

'They got up, drove him out of the town, and took him to the brow of the hill on which the town was built, in order to throw him down the cliff.'

This example clearly involves a bodily act, and although the translation uses the word throw it is likely that the intention of the crowd was to push Jesus so that he would fall off the cliff. In other words, Lunt's glossing of rinoti as 'push' may not be far off the mark. Was ringti a semelfactive verb? While the available evidence does not suffice to establish this with certainty, there is circumstantial evidence pointing in this direction. Since ringti displays a lexical meaning closely related to the handbased acts discussed above, for the purposes of the present study I will regard it as a bodily act with semelfactive meaning.

\subsection{Cue validity}

Since it appears that both mouth- and hand-based bodily acts provide good candidates for verbs with semelfactive meaning, the question now arises as to whether the semelfactive was grammaticalized as a morphological category marked by the suffix -no-. This question can be addressed in terms of "cue validity", which can be defined as the conditional probability that an item belongs to a particular category given a particular feature ("cue", cf. e.g. Bates and MacWhinney 1987,

\footnotetext{
15 Example cited from Codex Marianus. Codex Zographensis and Codex Assemanianus have the same form.
} 
Goldberg 2006: 105ff.). Goldberg discusses the relationship between verbs, constructions and sentence meaning. Are individual verbs such as get or constructions such as verb + object + path the best predictors (clues) of sentence meaning? Goldberg (2006: 106) argues that "speakers would do well to learn to attend to the constructions", since constructions provide a good basis for predicting the meaning of a sentence, while individual verbs like get occur in so many different kinds of constructions that they are of little help if one wants to predict the meaning of the sentence. In the following we are interested in the relationship between the suffix - nq- and semelfactive meaning. In other words, what is the probability that a verb belongs to the semelfactive category (i.e., has semelfactive meaning) if it has the suffix -no- (the cue)? The strongest case one could make is a one-to-one relationship between the suffix and the semelfactive meaning where all and only verbs with the -nq- suffix have semelfactive meaning. In this case the cue validity would be 1 , since on the basis of the -nq- suffix we would be in a position to predict semelfactive meaning with $100 \%$ certainty. However, there is no such one-to-one relationship in OCS; as we have seen, only a handful of verbs display semelfactive meaning, and there are several non-semelfactive verbs with -ng- in OCS.

If we count seven verbs with semelfactive meaning out of a total of 77 verbs with -no-, we can calculate the cue validity by dividing 7 by 77 , which gives a cue validity of $0.1 .^{16}$ Needless to say, a cue that allows you to predict membership in a category with $10 \%$ accuracy is not very valuable. However, this calculation glosses over the fact that the OCS -no--verbs represent a heterogeneous category. As is well known, some verbs preserve the nasal suffix throughout the paradigm, while other verbs have no nasal suffix in the past tense forms (aorist and participles). All the semelfactive verbs keep the nasal suffix throughout the paradigm, so it may be more meaningful to compare the number of semelfactives to the total number of verbs that keep the suffix throughout the paradigm, which is thirty. Within this subset, the cue validity of -no- is 0.2 . The semelfactive verbs we are interested in in the present study are all unprefixed. A relevant comparison is therefore between semelfactive verbs and all unprefixed verbs. Since there are 16 unprefixed -nq--verbs attested in OCS, the cue validity of -no- within the group of unprefixed verbs is 0.4 . If we compare the seven semelfactive verbs with the total number of unprefixed verbs that keep -no- throughout the paradigm-i.e., 11 verbs,- - the cue validity reaches 0.6 , which is comparable to the cue validities discussed by Goldberg (2006: $107 \mathrm{ff}$.).

The cue validities are summarized in Table 4. So far we have been concerned with type frequencies (numbers of verbs), but it stands to reason that token frequency is relevant as well (Goldberg 2006: 110); a highly frequent verb will

\footnotetext{
16 The total number of OCS verbs with -ng- is based on Nesset (2012), who counts unprefixed and prefixed verbs as different verbs, but who does not distinguish between different prefixations from the same stem, since the choice of prefix appears to have no effect on the behavior of -no-. Thus, gybnoti and pogybnoti are counted as different verbs, while pogybnoti and izgybnoti are not. If all prefixations from a stem are analyzed as different verbs, the total number of verbs with -no- will be higher. Nesset (2012), who analyzes plinoti and pljunoti as different verbs, arrives at a total of 78 verbs, but since there seems to be no semantic difference between the two stem variants, plinoti and pljunoti will be considered one verb in the following, and accordingly the total number of verbs in - $n Q$ - is 77.
} 
provide better cues than a verb that is used infrequently. Therefore, I have included cue validities based on token frequencies in the rightmost portion of the table. These are calculated by dividing the total number of attestations of semelfactive verbs (i.e., 74) by the total numbers of attestations in the relevant groups of -no--verbs given in the rightmost column of the table. Since the OCS religious texts may not reflect natural speech of any particular speech community at any particular point in history, the numbers in Table 4 should be taken with a grain of salt. However, it is interesting to see that the cue validities based on type and token frequencies are entirely parallel.

\begin{tabular}{lrrrr} 
& \multicolumn{2}{c}{ Type frequency } & \multicolumn{2}{c}{ Token frequency } \\
& \# verbs & Cue validity & \# examples & Cue validity \\
\hline All -ng--verbs & 77 & 0.1 & 1331 & 0.1 \\
All -ng--preserve verbs & 30 & 0.2 & 448 & 0.2 \\
All unprefixed -ng--verbs & 16 & 0.4 & 171 & 0.4 \\
All unprefixed - $n q$--preserve & 11 & 0.6 & 121 & 0.6
\end{tabular}

verbs (all perfective)

Table 4: Cue validity of -no- as a marker of the semelfactive aktionsart

In general, Table 4 shows that the association between the -no- suffix and semelfactive meaning is not very strong, although cue validity is much higher within the subgroup of unprefixed verbs that keep the nasal suffix throughout the paradigm. Although there is psycholinguistic evidence that speakers can make generalizations based on classes containing as few as six members (Bybee 2001: 29, 121 and 124), we are dealing with a very small class of semelfactive verbs in OCS. On this basis I conclude that the semelfactive aktionsart was in an embryonic state in OCS. In the following, we will see how it developed in Old Russian and Modern Russian.

\section{Old Russian: expansion}

In this section I will present and analyze a database of Old Russian verbs with the -nu- suffix. While my data do not indicate that the -nu-suffix increased its cue validity for the semelfactive aktionsart, the Old Russian evidence suggests that the semelfactive aktionsart spread to new types of verbs, notably auditory and optical verbs, and possibly also verbs of physical movement.

\subsection{Data and cue validity}

Compared to the OCS canon, Old Russian involves a larger and arguably more heterogeneous body of data-both temporally and genrewise. The term "Old Russian" covers a period of several centuries, according to some scholars from the $11^{\text {th }}$ through the $17^{\text {th }}$ centuries, which is the time span to be studied in the present article. ${ }^{17}$ The Old Russian texts belong to a variety of genres, ranging from birch

17 While it is customary to refer to the period from the 14th to the 17th centuries as "Middle Russian", for the purposes of the present study I will use the term "Old Russian" for the whole period from the 11 th to the 17 th centuries, since this is the period covered by the main dictionaries from which my 
bark letters, which represent a language close to the dialect of medieval Novgorod, to religious texts such as Saints' lives with Church Slavic linguistic features. In order to create a manageable and reasonably representative database, I excerpted manually all unprefixed verbs with -nu- from two major dictionaries (Sreznevskij 1893-1906 and Slovar' russkogo jazyka XI-XVII vv. 1975-). ${ }^{18}$ This is a feasible task due to the existence of the reverse index of Sreznevskij's dictionary by ObrebskaJablonska and Dulewicz (1968) and the reverse index of Slovar' russkogo jazyka XI$X V I I v v$. in the dopolnenija $i$ ispravlenija volume of that dictionary. The resulting database comprises 133 verbs, of which 48 are classified as perfective and semelfactive, 38 as perfective, but not semelfactive, and 39 as imperfective nonsemelfactive. ${ }^{19}$ ( 8 verbs could not be classified due to insufficient information in the relevant dictionaries.) The situation is summarized in the pie diagram in Figure 1. The non-semelfactive perfectives include verbs such as goneznuti 'avoid' and taknuti 'confirm', while the imperfective group comprises verbs like gasnuti 'go out (about light)' and zjabnuti 'get cold'. In the following we will explore only the semelfactive verbs.

database was constructed. While the decision to treat the whole period from $11^{\text {th }}$ through the $17^{\text {th }}$ centuries as "Old Russian" is controversial, it comes with the advantage of facilitating a study of the gradual change throughout this long period. Discussing individual examples or groups of examples, I will pay particular attention to their earliest attestation in order to establish whether they belong to the oldest layer of Old Russian or represent more recent innovations. Terminological alternatives to "Old Russian" include "Old Rusian" (with one $s$ ) and "Old East Slavic". For the purposes of this study I have chosen the most traditional and widespread term, namely "Old Russian".

${ }^{18}$ In order to avoid confounding factors, verbs with the Old Russian equivalent of the postfix -sja were not included in the database. In an ideal world, the reflexive clitic sę should have been avoided in OCS too, but in view of the small size of the OCS database, this was not possible.

${ }^{19}$ Notice that for the purposes of this study I count different spellings as orthographic variants of one verb. Thus, I consider grlknuti and golknuti variants of the same verb. Likewise, liznuti and leznuti are regarded as variants of the same verb. In this way, I follow the lemmatization practice of Slovar' russkogo jazyka XI-XVII vv. (1975-). 


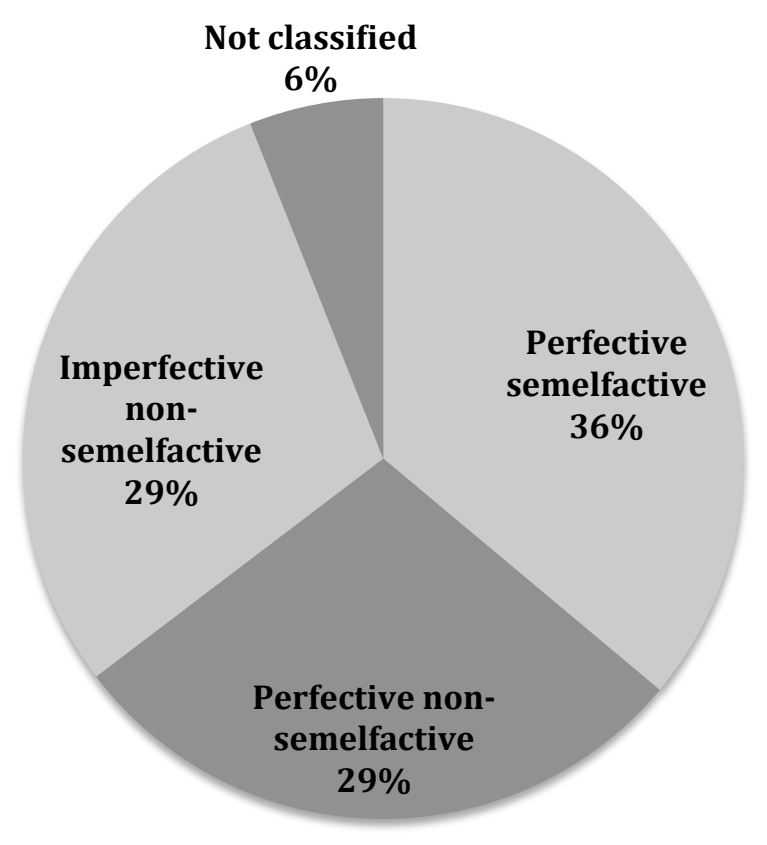

Figure 1: $\mathrm{Nu}$-verbs in Old Russian

Although many researchers (c.f. e.g. Silina 1982) acknowledge the existence of a semelfactive aktionsart in Old Russian, the task of classifying individual verbs with regard to aspect and aktionsart is far from trivial, since the dictionaries do not consistently provide such information. For the purposes of the present study, I regard verbs that are glossed by perfective verbs as perfective, and verbs with imperfective glosses as imperfective. In a similar vein, verbs are considered semelfactive if they are marked as odnokr. in the dictionaries or are glossed by semelfactive verbs. In a few cases, the definition given in the dictionaries includes a phrase that is equivalent to a semelfactive verb, although, strictly speaking, no semelfactive verb is used. For instance, krjaknuti is defined as izdat' krik, krjakan'e (ob utke); since izdat' krik may be considered the equivalent of the semelfactive verb kriknut', krjaknuti is classified as a semelfactive verb as well. Admittedly, using glosses from dictionaries may not be an ideal methodology since it to some extent relies on modern Russian. However, the methodology was applied in a conservative way, and as shown in Figure 1 yielded a sizeable proportion of verbs in the perfective non-semelfactive category. It is likely that some of the verbs that were classified as non-semelfactive may display semelfactive meaning, but for methodological reasons I prefer to focus on verbs for which we have clear indications of semelfactive meaning. In the following, we will consider text examples in order to see how these verbs were used.

The database facilitates an assessment of the validity of the -nu- suffix as a cue for the semelfactive aktionsart in Old Russian. If we consider all non-prefixed verbs in -nu-, the cue validity is 0.4 , since 48 out of 133 verbs are semelfactive. If we instead narrow down our focus to perfective verbs, we get a cue validity of 0.6 , because 48 out of 88 unprefixed perfective verbs with -nu- are semelfactive. If we 
compare these numbers with the OCS data in Table 4, we see that the cue validities in Old Russian are not higher than in OCS. In other words, the quantitative analysis does not indicate that the semelfactive aktionsart has strengthened its position in Old Russian compared to OCS.

However, qualitative analysis of the verbs in -nu- offers some evidence for a strengthening of the semelfactive in Old Russian, insofar as the semelfactive appears to have expanded to more types of verbs. The remainder of this section is devoted to qualitative analysis of verb semantics.

\subsection{Bodily acts}

In sections 3.2 and 3.3, we explored OCS semelfactive verbs among "bodily acts", i.e., verbs where an agentive subject carries out an action by means of a body part. It comes as no surprise that there are numerous such semelfactives in Old Russian as well; of the 48 semelfactives in my database 32 were classified as bodily acts. For the convenience of the reader, a full list is given in Table 5 .

$\begin{array}{llll}\text { bryznuti } & \text { 'splash' } & \text { lunuti } & \text { 'shoot' } \\ \text { bręznuti } & \text { 'hit' } & \text { manuti } & \text { 'nod, gesture' } \\ \text { grenuti } & \text { 'row, rake' } & \text { maxnuti } & \text { 'wave' } \\ \text { dunuti } & \text { 'blow' } & \text { pixnuti/pexnuti } & \text { 'blink' } \\ \text { dzxnuti } & \text { 'breathe' } & \text { liznuti } & \text { 'lick' elbow' } \\ \text { dyxnuti } & \text { 'breathe' } & \text { plesnuti } & \text { 'clap one's hands, splash' } \\ \text { dbrnuti } & \text { 'pull, tug' } & \text { pljunuti } & \text { 'spit' } \\ \text { zěvnuti } & \text { 'yawn' } & \text { pnuti } & \text { 'kick' } \\ \text { iknuti } & \text { 'hiccup' } & \text { 'splash' } \\ \text { kačnuti } & \text { 'rock, swing, shake' } & \text { prysnuti } & \text { 'jab' } \\ \text { kašljanuti } & \text { 'cough' } & \text { pyrnuti } & \text { 'push' } \\ \text { kivnuti } & \text { 'nod' } & \text { rinuti } & \text { 'break, chop, split' } \\ \text { kolsnuti } & \text { 'break, chop, split' } & \text { strbknuti } & \text { 'push' } \\ \text { kopanuti } & \text { 'dig' } & \text { tzlknuti } & \text { 'drink down' } \\ \text { kosnuti } & \text { 'touch' } & \text { xlebnuti } & \text { 'cough up' } \\ \text { laknuti } & \text { 'lap' } & \text { xraknuti } & \end{array}$

Table 5: Semelfactive bodily acts in Old Russian

A familiar item in Table 5 is pljunuti 'spit', the OCS equivalent of which we explored in some detail in section 3 above. The following example shows that Old Russian pljunuti is used in the same way as its OCS counterpart:

(17) Si slyšavъ, Volodimirъ pljunu na zemlju, rekъ: «Nečisto estı dělo» (Primary Chronicle for the year 986$)^{20}$

"When he heard this, Vladimir spat on the ground and said: "This is dirty business"'.

20 Cited from http://lib.pushkinskijdom.ru/Default.aspx?tabid=4869 
This is a non-resultative verb that corresponds to an imperfective activity verb describing a series of uniform subevents, and since we are dealing with a single and instantaneous act, Old Russian pljunuti here behaves like a prototypical semelfactive verb. The similarities between (17) and the OCS examples discussed in section 3 are hardly surprising, since the occurrence of spitting in the Bible must have been familiar to the authors of the Primary Chronicle. For instance, according to Slovar' russkogo jazyka XI-XVII vv. (1975-), the Ostromirovo Evangelie from 1056-57 has the aorist plinu in John 9.6, parallel to the OCS sources (cf. example (6) above).

The Primary Chronicle has come down to us in a number of sources, the oldest of which is the Laurentian Codex from 1377, but it is likely that example (17) reflects language use of the $12^{\text {th }}$ century when the chronicle was presumably compiled. All the sources cited in Ostrowski's (ed.) (2003: 636) interlinear collation and paradosis have the aorist pljunu (or the variant bljunu) or the participle pljunuvb, and all the major editions Ostrowski cites reconstruct pljunu.

Table 5 also contains a number of "hand-based" acts, i.e., verbs involving hand movements, such as rinuti 'push' and pixnuti 'push'. Rinuti is attested in the so-called kratkaja redakcija of Russkaja Pravda:

(18) Ašče li rinetb mužb muža ljubo ot sebe ljubo $\mathrm{k}$ sobě, 3 grivně, a vidoka dva vyvedetb. (Akademičeskij I spisok, cited after Grekov (ed.) 1940/1967: 70)

'If a man pushes another man either away from or towards himself, then he has to pay 3 grivnas if two witnesses are presented.'

This example is compatible with a semelfactive interpretation, insofar as the conditional construction describes the consequences of a potential single instantaneous act of pushing in the future. The kratkaja redakcija is preserved in two sources from the $15^{\text {th }}$ century, but it is possible that (18) reflects language use in the $11^{\text {th }}$ century when the kratkaja redakcija was first written down, since both existing sources have rinetb (cf. Grekov (ed.) 1940/1967: 70 and 79). ${ }^{21}$

Whereas rinuti is attested in the kratkaja redakcija of Russkaja Pravda as shown in (18), the later prostrannaja redakcija has a different verb in the corresponding passage that also permits a semelfactive reading:

(19) Ili pьxnetb mužb muža ljubo k sobě li ot sebe, ljubo po licju udaritb, li žerdьju udaritb, a vidoka dva vyvedutb, to 3 grivny prodaže. (Sinodal'nyj I spisok, cited after Grekov (ed.) 1940/1967: 125)

\footnotetext{
${ }^{21}$ Another early attestation of rinuti in Old Russian comes from birch bark letter no. 227, which is dated to 1160-1190 (Zaliznjak 2004: 375). This letter contains the phrase torogo rinevb, which Zaliznjak (2004: 377) speculates may mean 'the two of us will give up trade', i.e., with a first person dual present tense (with future meaning) of rinuti. However, as Zaliznjak points out, this interpretation is uncertain, because only a fragment of the letter has been preserved. Beyond showing that the verb rinuti was used in early Old Russian, birch bark letter no. 227 does not shed much light on the semelfactive aktionsart, since on Zaliznjak's interpretation rinuti is used in the metaphorical sense 'stop, give up', rather than the concrete 'push, throw'.
} 
'If a man pushes another man towards or away from himself or hits him on the face with a stick, and the aggrieved party presents two witnesses, then he shall pay 3 grivnas.'

The prostrannaja redakcija, which may have been compiled in the first half of the $12^{\text {th }}$ century before the fragmentation of the Kiev state (Sverdlov 2006-2011), has come down to us in a number of versions; (19) cites the oldest one, which is dated to 1282 (Grekov (ed.) 1940/1967: 123). Interestingly, instead of unprefixed pьxnetb some sources have the prefixed popzxnetb in the relevant passage. Although the prefixed verb is mostly attested in younger sources, the evidence adduced in the present study does not suffice to establish whether the protograph had a prefixed or an unprefixed verb. However, in any case it seems clear that the unprefixed semelfactive was used in Old Russian in the $13^{\text {th }}$ century.

\subsection{Auditory verbs}

The OCS data explored in section 3 do not contain any semelfactive verbs among auditory verbs, i.e., verbs where the subject (mostly an animal or a human) produces a sound. However, as shown in Table 6, my Old Russian database comprises 13 such verbs. In order to illustrate their use as semelfactive verbs, I will comment on two of them, namely svistnuti 'whistle' and njuknuti 'scream, call'.

$\begin{array}{llll}\text { brexnuti } & \text { 'yelp, bark' } & \text { lanuti } & \text { 'bark' } \\ \text { vizgnuti } & \text { 'squeal, yelp' } & \text { lusnuti } & \text { 'rustle' } \\ \text { garknuti } & \text { 'bark, bawl' } & \text { njuknuti } & \text { 'scream, call' } \\ \text { golknuti } & \text { 'roar, rumble' } & \text { pyxnuti } & \text { 'snort' } \\ \text { kriknuti } & \text { 'scream' } & \text { ryknuti } & \text { 'roar' } \\ \text { krjaknuti } & \text { 'quack' } & \text { svistnuti } & \text { 'whistle' } \\ \text { kyrknuti } & \text { 'caw, croak' } & & \end{array}$

Table 6: Semelfactive auditory verbs in Old Russian

The oldest attestation of svistnuti mentioned in Slovar' russkogo jazyka XI-XVII vv. (1975-) is from Slovo o prlku Igoreve:22

(20) Komonь vъ polunoči Ovlurъ svisnu za rbkoju — velitı knjazju razuměti: knjazju Igorju ne bytb!

'Bringing a horse at midnight, Ovlur whistled beyond the river: he bids Igor heed-Igor is not to be held in bondage.'

Although it is difficult to establish exactly what kind of action Igor's helper Ovlur performed, the example is compatible with an interpretation as a semelfactive verb, whereby Ovlur produced a single instantaneous whistle sound in order to signal to Igor that help was on its way. Indeed, it is likely that Ovlur would keep his whistling to an absolute minimum in order not to make the guards who were watching over

${ }^{22}$ Cited from http://lib.pushkinskijdom.ru/Default.aspx?tabid=4941\#_ednref95. The translation is by Nabokov (1960). 
Igor suspicious. It is worth noting that the modern Russian translations by Lixačev (cf. Ponyrko (ed.) 1983: 409), Botvinnik (Dmitriev and Lixačev (eds.) 1967: 306), Rylenkov (Dmitriev and Lixačev (eds.) 1967: 330), and Stepanov (Dmitriev and Lixačev (eds.) 1967: 353) use the semelfactive verb svistnut' in this passage, thus suggesting that we are dealing with a single instantaneous whistling act in (20). On the assumption that Slovo o prlku Igoreve was written shortly after Igor's campaign took place in 1185, example (20) provides evidence in favor of the existence of auditory semelfactive verbs towards the end of the $12^{\text {th }}$ century. ${ }^{23}$

From Zadonščina we have the following attestation of njuknuti 'scream, call':24

(21) I njuknuv knjazı Vladimerъ Andrěevičs gorazdo, i skakaše po rati vo polcex poganyx $\mathrm{v}$ tatarskix, a zlačenym šelomom posvěčivajuči.

'Prince Vladimir Andrěevič' called out (the war-cry) and was rushing with his army towards the regiments of the heathen Tatars, his gilded helmet shimmering (in the sun)'

It stands to reason that prince Andrej produced one single, instantaneous cry before the Russian troops started advancing against the Tatars, so (21) provides a good example of prototypical semelfactive verb usage from the late 14th century. It is worth noting that the modern Russian translation by L. A. Dmitriev (2005-2011) renders njuknuv as kliknuv klič 'having called out the war-cry' with the semelfactive verb kliknut'.

\subsection{Optical verbs}

In addition to the bodily acts and auditory verbs listed in Tables 5 and 6, my database of Old Russian semelfactives contains two optical verbs, blesnuti and melbkanuti, which both mean 'flash'. The earliest attestation mentioned in Slovar' russkogo jazyka XI-XVII vv. (1975-) is from the description of the year 1389 in the Patriaršaja (Nikonovskaja) letopis':

(22) I srěte ego vъ totarskixъ polexъ, na Donu na rěcě, i sostupišasja, aki silnii tuči, blesnuša oružia, aki molnia vъ denь doždja... (Polnoe sobranie russkix letopisej vol. 11, page 111)

'And at his encounter in the Tatar fields on the river Don they gathered like strong clouds and their weapons flashed like the lightning on a rainy day...'

The comparison with the lightning suggests that we are dealing with an instantaneous flash, thus providing evidence for the semelfactive use of blesnuti in Old Russian. The Patriaršaja (Nikonovskaja) letopis' is preserved in sources that go

\footnotetext{
${ }^{23}$ For over two centuries since Slovo o pzlku Igoreve was first published in 1800, there have been doubts as to its authenticity. However, Zaliznjak's (2007) masterful analysis of a variety of factors including clitic placement, dialectal features and scribal errors has laid these doubts to rest. From Zaliznjak's analysis it is clear that Slovo o pzlku Igoreve must have been written before Zadonšcina, and as Zaliznjak (2007: 8) points out, most researchers suggest that it was written shortly after 1185, when Igor's campaign took place.

${ }^{24}$ Cited after: http://lib.pushkinskijdom.ru/Default.aspx?tabid=4980
} 
back to the 16th century (Kloss 1980: 4), but example (22) may reflect language usage at a time closer to the historical events described in the chronicle.

The second optical verb, melbkanuti, has the variant -anu- of the semelfactive suffix, which is otherwise only attested twice in my database (kašljanuti 'cough' and kopanuti 'shovel').

(23) Čelověkъ liše by vъ okoško pogljanulъ ili mežъ zubcovъ melıkonulъ, anъ by ego i ubilъ. (letter from 1700, cited after Slovar' russkogo jazyka XI-XVII vv. 1975-)

'If a person would only see someone through the window or glimpse him between the boards of a picket fence, he would kill him.'

It is unclear from the example whether melbkanuti has the intensifying or expressive meanings often associated with -anu- (cf. e.g. Isačenko 1982: 402, Kuznetsova and Makarova 2012: 156, Makarova and Janda 2009: 90, Sigalov 1963: 70, Švedova (ed.) 1980: 349 and Zaliznjak and Šmelev 2000: 119), but it is clear that we are dealing with a sudden glimpse, which accords well with an interpretation of melbkanuti as a semelfactive verb. Although optical verbs form a small subcategory, they are theoretically interesting since, as opposed to the remaining subcategories, optical verbs do not have agentive subjects. While agentive subjects are the norm for semelfactives in Old Russian, the optical verbs show that this is not an absolute requirement.

\subsection{Verbs of physical movement}

The final subcategory of Old Russian semelfactives is verbs of physical movement, of which I have one example in my database, viz. nyrnuti 'dash off, disappear suddenly'. Verbs of physical motion differ from bodily acts in that the whole body moves to another position. Although a single example is not sufficient to draw definite conclusions, the following example from archpriest Avvakum's pen permits a semelfactive interpretation, since it describes the sudden movement of a dog that escapes from a wolf:

(24) Makarъ Antioxijskij zaběžalı vъ Gruzi, jako pesъ oţ volka v podvorotnju nyrnulъ, da podъ lesnicu sprjatalsja. (Avvakum 1677 cited after Slovar' russkogo jazyka XI-XVII vv. 1975-)

'M. A. fled to G. like a dog escaping from a wolf by dashing under a gate and hiding under a staircase.'

Before we leave the verbs of physical movement, it should be pointed out that there are verbs of physical movement with a nasal suffix in OCS that like nyrnuti describe movement away from something. However, the OCS verbs goneznoti 'avoid' and izbegnoti 'flee from' do not seem to have had semelfactive meanings.

\subsection{A radial category}

We have now seen that there is evidence that four types of verbs display semelfactive meanings in Old Russian: bodily acts, auditory verbs, optical verbs and 
verbs of physical movement. I argue that these verb types constitute a radial category, i.e., a network of related subcategories organized around a prototype, as shown in Figure 2. The figure lends additional support to the main theoretical idea behind the present study, namely that the radial category is a valuable tool for the diachronic analysis of the semelfactive aktionsart (and similar categories). In section 2, we saw that the very concept of "semelfactive" can be analyzed as a radial category structured around a prototype defined by four properties. Figure 2 shows that the various verb types that form semelfactives also constitute a radial category. Each subcategory is represented by a circle, which in addition to the name of the relevant verb type includes the number of verbs in the subcategory and the approximate date of the first attestation discussed above. For the convenience of the reader, the thickness of the circles also gives an indication of the relative size of the subcategories (subcategories with more members have thicker lines). The dashed arrows connecting the circles stand for metonymical relations, i.e., contiguity relations such as PART-WHOLE and CAUSE-EFFECT. ${ }^{25}$ The relation between bodily acts and verbs of physical movement is of the PART-WHOLE type; while bodily acts involve movement of a body part (e.g. the hand), verbs of physical movement describe movement of the body as a whole. Auditory verbs are also metonymically related to bodily acts. Whereas bodily acts such as pljunuti 'spit' denote an action involving the mouth, auditory verbs like njuknuti 'scream, call' focus on the sound that is the result of a mouth-based act. In other words, we are dealing with a CAUSE-EFFECT relationship between movement in the mouth and the resulting sound. ${ }^{26}$ In a similar way, the optical verbs involve a body part, namely the eyes, but the focus is on the optical impression, not on the eyes' activity as such. The double-headed arrow between auditory and optical verbs represents the relationship between the two verb types that both involve sensory impressions (auditory or visual). Since bodily acts are not only the subcategory with the most members, but are also directly

\footnotetext{
25 In recent years, there has been lively discussion in cognitive linguistics about the definition of metonymy. Some scholars have defined metonymy as relationships within a cognitive model or domain (as opposed to metaphor that involves relationships across domains, cf. e.g. Radden and Kövecses 1999 and Panther and Thornburg 1999). However, Peirsman and Geeraerts (2006) find the notion of "domain" imprecise and argue for a more traditional approach, whereby metonymy is defined in terms of contiguity relations. This debate is tangential to the present study, insofar as the relations in Figure 1 can be recognized as metonymy regardless of which definition one adopts. However, it is interesting to note that Peirsman and Geeraerts (2006) propose a definition in terms of a radial category, where some metonymic relations are more prototypical than others. In this way, Peirsman and Geeraerts' (2006) approach to metonymy parallels the prototype-based approach to the semelfactive aktionsart adopted in the present study.

${ }^{26}$ Another indication of the close relationship between bodily acts and auditory verbs is the fact that there exist a number of borderline cases between the two subcategories, since bodily acts are often accompanied by sound. Kašljanuti 'cough' and xraknuti 'cough up' are classified as bodily acts, since the sounds here seem secondary. Pyxnuti 'snort', on the other hand, is included in the subcategory of auditory verbs, since this verb essentially means to express anger by means of a sound produced by breathing loudly through the nose. A more realistic model would be to consider verbs like kašljanuti, xraknuti and pyxnuti to be members of both subcategories at the same time. For simplicity I have avoided overlapping subcategories in this study, but it should be noticed that there is nothing in the theory behind radial categories that would preclude simultaneous membership in more than one subcategory.
} 
related to all the other subcategories through metonymy, I consider bodily acts the prototype, i.e., the central subcategory in the radial category network.

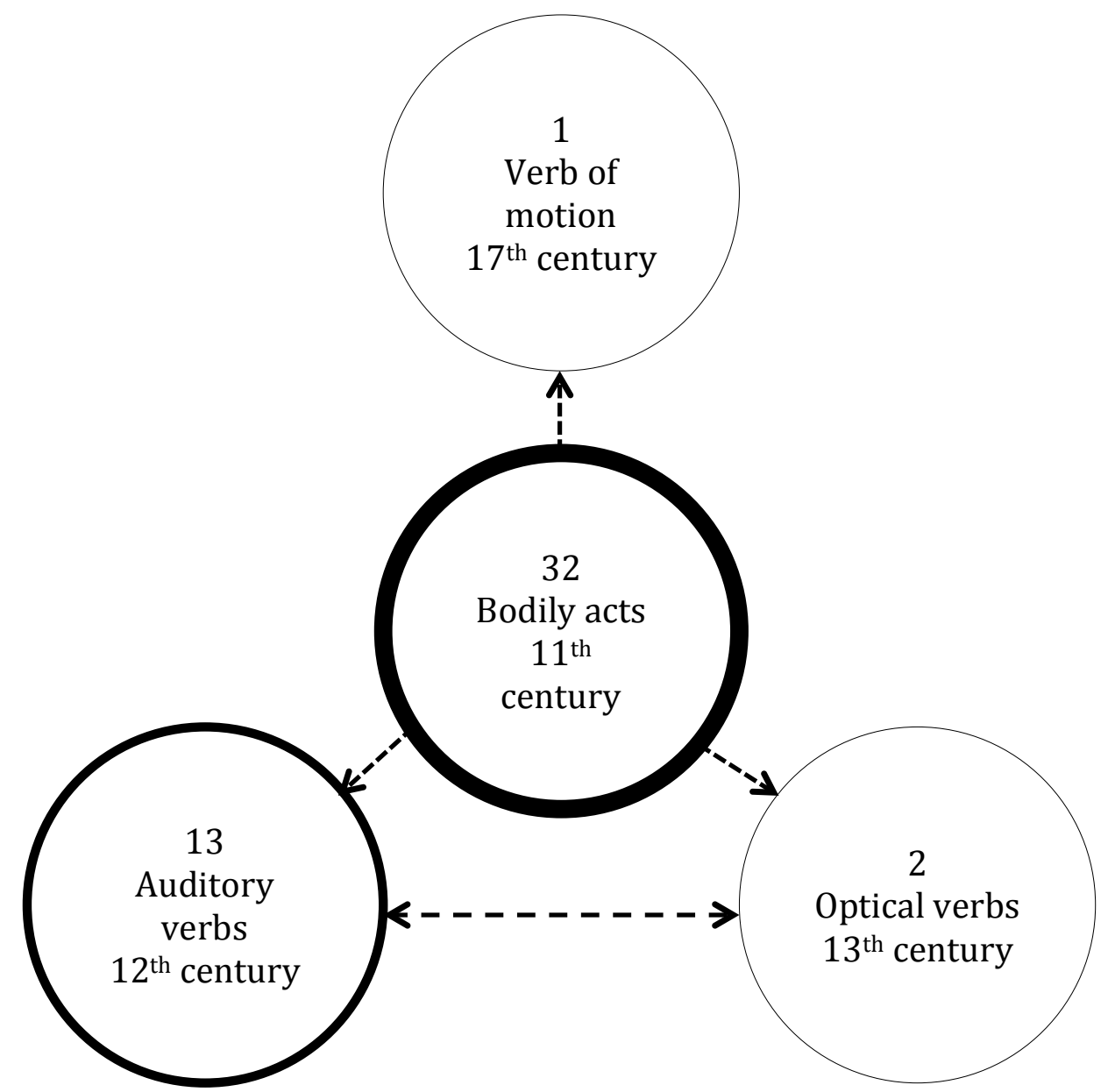

Figure 2: Radial category network for verb types with semelfactive meaning

Figure 2 facilitates comparison of semelfactives in OCS and Old Russian. In the previous section we saw that all the attested OCS semelfactives were bodily acts, so it seems that semelfactives were compatible with a more narrowly defined range of verb types in OCS compared to Old Russian. How can we understand this difference? Two interpretations come to mind. First, it is possible that the semelfactive aktionsart had a very narrow distribution in Late Common Slavic (as indicated by the OCS data), but that the semelfactive aktionsart then spread to more verb types in Old Russian. However, an alternative interpretation is also conceivable, whereby the broader distribution of attested semelfactives in Old Russian is simply due to the fact that Old Russian represents a much larger and more diverse body of texts than OCS. In other words, according to this alternative hypothesis, if the OCS corpus had been larger and comprised more genres, we would have had attestations of semelfactive auditory, optical and verbs of physical movement in OCS. Although the data summarized in Figure 2 clearly do not suffice to settle the issue, these data may speak in favor of an intermediate position. Since auditory verbs represent a relatively large group for which we have early attestations, semelfactive verbs of 
this type may have existed in Late Common Slavic, even though the OCS canon does not contain such examples. In view of the fact that we have fewer optical and verbs of physical movement and that the attestations are somewhat later, these subcategories may reflect later innovations during the Old Russian period. However, given the limited amount of data, this interpretation remains somewhat speculative, and further empirical work is required in order to confirm or disconfirm it.

\section{Contemporary Standard Russian: continued expansion}

Since the semelfactive aktionsart in CSR is better understood than in Old Russian and OCS, a less detailed discussion of the CSR data is sufficient for the purposes of the present article. However, I will present data suggesting that the radial category's center of gravity is in the process of shifting from bodily acts to auditory verbs. Further indication of the expansion of the semelfactive aktionsart through the verbal lexicon is the emergence of semelfactive verbs outside the four subcategories attested in Old Russian.

Kuznetsova and Makarova (2012), who studied the relationship between -nu- and -anu-, have created a database of $2101 n u$-verbs excerpted from the Russian National Corpus. ${ }^{27}$ Since the semelfactive $n u$-verbs represent a productive pattern in CSR (cf. e.g. Švedova (ed.) 1980: 349 and Dressler and Gagarina 1999), it is not unexpected that Kuznetsova and Makarova's database contains a large number of "occasionalisms" that are attested only a few times in the corpus. Such low-frequent verbs may have existed in Old Russian too, but they would most likely not be attested in the manuscripts that have come down to us, since the existing body of Old Russian texts is much smaller and more restricted with regard to genre than the modern Russian texts available in the Russian National Corpus. In order to facilitate meaningful comparison with Old Russian, all semelfactive $n u$-verbs with 50 or more attestations in the Russian National Corpus were culled from Kuznetsova and Makarova's database. All prefixed verbs and verbs containing the postfix -sja were excluded. The result was a dataset of 110 highfrequent verbs, which represent the well established, conventionalized part of the semelfactive category in CSR.

Before we consider lists of verbs and discuss the semantics of individual verbs, let us consider Table 7 and Figure 3 , which compare the distribution of semelfactives in CSR and Old Russian. The table shows the frequencies of the various semantic types in raw numbers and percent, while the figure compares percentages. (In addition to information about high frequency verbs, the table also includes information about low frequency verbs, to which we will return below.) The table shows that the distribution for high-frequency verbs in CSR is very similar to the distribution in Old Russian. Admittedly, the percentage of bodily acts is slightly lower in CSR (55\% in CSR vs. $67 \%$ in Old Russian), but this difference is not statistically significant. ${ }^{28}$ However, Table 7 and Figure 3 include two differences that

${ }^{27}$ I would like to express my gratitude to Julia Kuznetsova and Anastasia Makarova who generously shared their data with me.

${ }^{28}$ Pearson's Chi-squared test $(\mathrm{X}$-squared $=2.7237, \mathrm{df}=2$ ) gave $\mathrm{p}$-value $=0.2562$, which indicates that the difference is not statistically significant. In this test I compared auditory verbs, bodily acts, and 
are worth mentioning. First, there is a small subcategory of "miscellaneous verbs" that do not match any of the verb types attested in Old Russian. By way of example consider psixanut' 'freak out':

(25) Terpel, terpel grubuju reč” v adres svoego tovarišča i vdrug psixanul: «Začem vy unižaete aktera?» [Smexov 2001]

'I was putting up with his foul language directed at my friend, but suddenly I freaked out: "Why are you humiliating the actor?"'

The full list of "miscellaneous verbs" in Table 8 shows that we are dealing with verbs that denote certain types of behavior, or, to be more precise, instantaneous episodes of such behaviors. Some of the verbs are related to bodily acts. For instance, kozyrnut' 'play trump' typically involves a hand movement whereby a card is placed on the table. Nevertheless, kozyrnut' is not classified as a bodily act, since the focus is on this action's meaning in the card game, rather than on the physical gesture. Although miscellaneous verbs constitute only $5 \%$ of the high-frequent CSR $n u$-verbs in Table 7, they indicate that the semelfactive aktionsart has spread to new types of verbs in CSR. Admittedly, we cannot categorically exclude the existence of behavior semelfactives in Old Russian, but such verbs must have been less frequent if they existed at all, since they are not attested in the Slovar' russkogo jazyka XI-XVII vv. (1975-) or Sreznevskij (1893-1906).

\begin{tabular}{lrrrrrr} 
& \multicolumn{2}{c}{ Old Russian } & \multicolumn{2}{r}{ CSR (high frequent) } & \multicolumn{2}{c}{ CSR (low frequent) } \\
& $\#$ & $\%$ & $\#$ & $\%$ & $\#$ & $\%$ \\
\hline Auditory verbs & 13 & 27 & 33 & 30 & 99 & 39 \\
Bodily acts & 32 & 67 & 61 & 55 & 87 & 34 \\
Verb of phys. & 1 & 2 & 5 & 5 & 15 & 6 \\
movement & & & & & & \\
Optical verbs & 2 & 4 & 5 & 5 & 1 & 1 \\
Miscellaneous & 0 & 0 & 6 & 5 & 51 & 20 \\
Total & 48 & 100 & 110 & 100 & 253 & 100
\end{tabular}

Table 7: Distribution of semelfactives in Old Russian and CSR (high frequency and low frequency verbs, data on CSR from Kuznetsova and Makarova 2012)

other verbs (i.e., the sum of miscellaneous verbs, verbs of physical movement and optical verbs). I also carried out the same test, but excluded the category "other verbs" in order to test for the relative strength of the two largest subcategories, viz. auditory verbs and bodily acts. This test gave p-value = 0.5918 (X-squared $=0.2876, \mathrm{df}=1$ ). This is a clear indication that there is no statistically significant difference between the distribution of auditory verbs and bodily acts in my Old Russian and CSR datasets. 


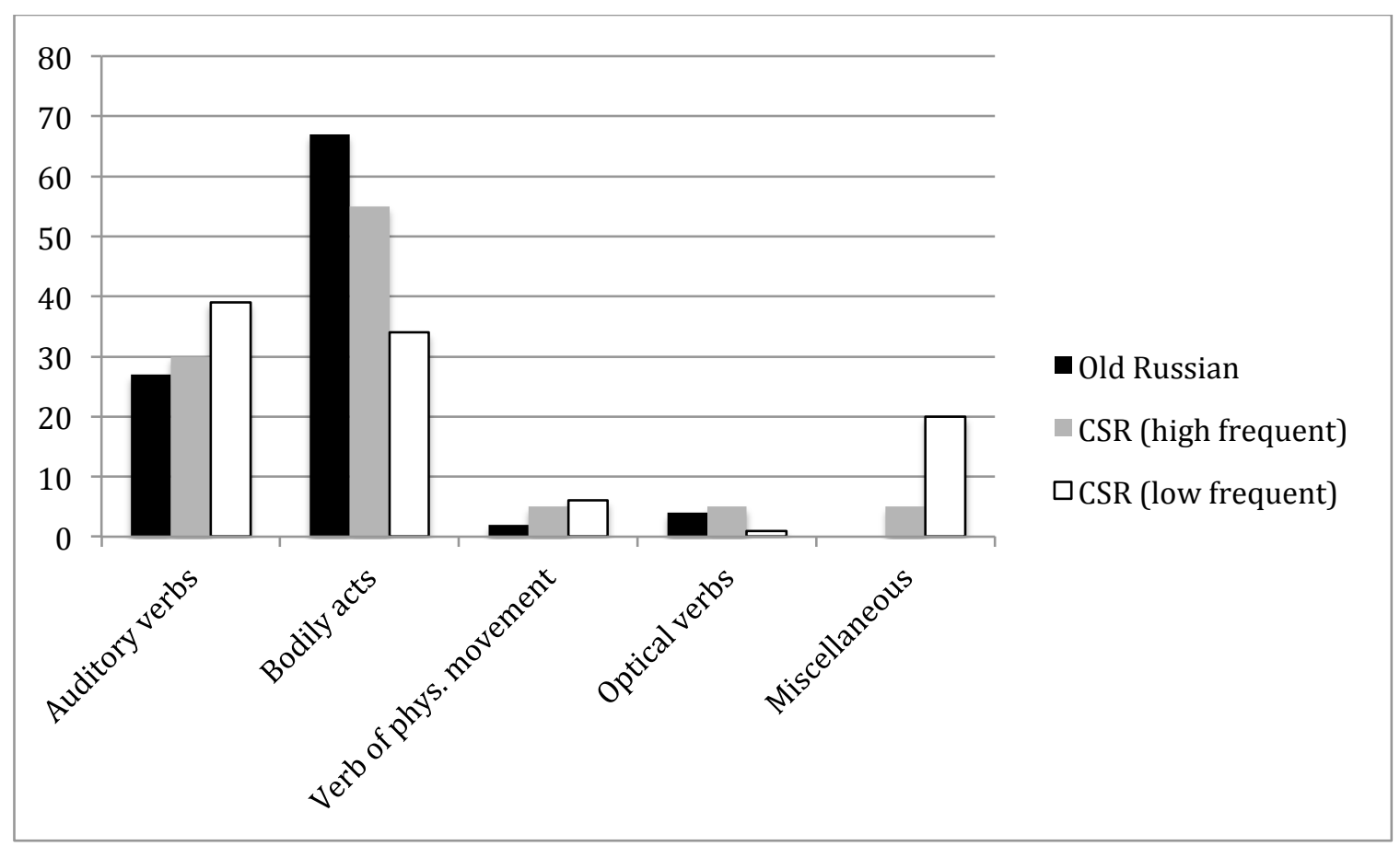

Figure 3: Distribution of semelfactives in Old Russian and CSR (high frequency and low frequency verbs, data on CSR from Kuznetsova and Makarova 2012)

$\begin{array}{llll}\text { gul'nut' } & \text { 'make merry' } & \text { psixanut' } & \text { 'freak out' } \\ \text { ljapnut' } & \text { 'blurt out' } & \text { risknut' } & \text { 'take a risk' } \\ \text { kozyrnut' } & \text { 'play a trump' } & \text { šuganut' } & \text { 'scare off' }\end{array}$

Table 8: Behavioral/miscellaneous verbs with 50 or more attestations in the RNC (according to Kuznetsova and Makarova 2012)

Another indication of the expansion of the semelfactive aktionsart in CSR comes from auditory verbs. As shown in Table 6 in section 4, in Old Russian the vast majority of these verbs denote sounds that humans or animals produce by means of their mouths, e.g. svistnuti 'whistle'. Semelfactive verbs like svistnut' are indeed attested in CSR as well, but in addition the CSR auditory verbs include a number of verbs denoting ringing sounds. In Table 9, which lists all the auditory verbs with at least 50 corpus attestations, the verbs that are not (primarily) mouth-based are given in boldface. On the assumption that such semelfactive verbs did not exist in Old Russian, or at least were too infrequent to be mentioned in the major dictionsaries, the boldfaced verbs in Table 9 offer some evidence for the expansion of the semelfactive aktionsart to new types of verbs in CSR.

$\begin{array}{llll}\text { axnut' } & \text { 'sigh' } & \text { oxnut' } & \text { 'moan, groan; sigh' } \\ \text { brjaknut' } & \text { 'clatter' } & \text { pisknut' } & \text { 'give a squeak' } \\ \text { bul'knut' } & \text { 'gurgle' } & \text { ryknut' } & \text { 'roar' } \\ \text { burknut' } & \text { 'mutter' } & \text { rjavknut' 'bellow, roar' } \\ \text { vjaknut' } & \text { 'speak indistinctly, blather' } & \text { svistnut' } & \text { 'whistle' } \\ \text { gavknut' } & \text { 'bark' } & \text { skripnut' } & \text { 'squeak' } \\ \text { garknut' } & \text { 'bark' } & \text { fyrknut' } & \text { 'snort' }\end{array}$




$\begin{array}{llll}\text { gromyxnut' } & \text { 'rumble' } & \text { xixiknut' } & \text { 'giggle' } \\ \text { eknut' } & \text { 'go pit-a-pat' } & \text { xmyknut' } & \text { 'hem, clear one's throat' } \\ \text { zvjaknut' } & \text { 'jingle, tinkle' } & \text { xoxotnut' } & \text { 'guffaw' } \\ \text { klacnut' } & \text { 'chatter (about teeth)' } & \text { xrjuknut' } & \text { 'grunt (of a pig)' } \\ \text { kliknut' } & \text { 'call, hail' } & \text { coknut' } & \text { 'clatter' } \\ \text { kriknut' } & \text { 'scream' } & \text { čixnut' } & \text { 'sneeze' } \\ \text { krjaknut' } & \text { 'quack' } & \text { šarknut' 'shuffle' } \\ \text { ljazgnut' } & \text { 'clank, clang' } & \text { šepnut' } & \text { 'whisper' } \\ \text { mjauknut' } & \text { 'mew, miaow' } & \text { ščlknut' 'flick, click' } \\ \text { ojknut' } & \text { 'cry “oh!"' } & & \end{array}$

Table 9: Semelfactive auditory verbs in CSR. Verbs not related to the mouth are boldfaced.

Although the behavior/miscellaneous verbs and the non-mouth-based auditory verbs discussed above suggest that the distribution of semelfactive verbs has changed over time, the differences between Old Russian and CSR are far from dramatic. However, so far we have only considered high-frequent semelfactives in CSR. Let us now turn to low-frequent verbs. If verbs with very few attestations show the same distribution as the high-frequent verbs, this would be an indication of stability over time. If, on the other hand, the peripheral subcategories are larger among the low-frequent verbs, this may indicate language change in progress, since the low-frequent verbs often represent recent innovations that have not yet become entrenched in the standard language. In order to find out what the situation is, I classified all the verbs from Kuznetsova and Makarova's (2012) database that have three or fewer attestations in the RNC. ${ }^{29}$ Once again, prefixed verbs and verbs containing the postfix -sja were excluded. The resulting dataset contains 253 verbs. The distribution of these verbs is given in the two rightmost columns in Table 7.

As shown in Table 7, there are two differences between the high- and lowfrequent verbs that deserve mention. First of all, the relative strength of bodily acts and auditory verbs is different in low-frequent verbs. While bodily acts are the largest verb type among the high-frequent verbs with 55\%, among the low-frequent verbs auditory verbs constitute a larger group than bodily acts (39\% vs. 34\%). Although this is a statistically significant difference, the effect size is small. ${ }^{30}$ In other words, we are dealing with a small, but significant shift of the center of gravity from bodily acts to auditory verbs.

The second difference between the high-frequent and low-frequent verbs in Table 7 concerns the "miscellaneous verbs". While only $6 \%$ of the high-frequent verbs were in the miscellaneous category, this category constitutes $20 \%$ of the lowfrequent verbs. This is a statistically significant difference, and the effect size is

\footnotetext{
${ }^{29}$ I am indebted to Anastasia Makarova for help with the semantic classification of these verbs, which are often not included in dictionaries. Notice that the Russian National Corpus has been expanded since Kuznetsova and Makarova created their database, so some of the verbs listed in Table 10 may have more than three attestations today.

30 Pearson's Chi-squared test with Yates' continuity correction (X-squared $=5.3065, \mathrm{df}=1) \mathrm{gave} \mathrm{p}$ value $=0.02$. Cramer's V-value, a measure of effect size, equals 0.1 , which indicates a small effect size (King and Minium 2008). Notice that for these tests I compared the numbers for auditory verbs and bodily acts without including the other subcategories.
} 
small to moderate. ${ }^{31}$ Since the miscellaneous type is somewhat stronger for lowfrequent frequent verbs, we are witnessing an expansion of the semelfactive aktionsart to new types of verbs.

All the low-frequent verbs in the miscellaneous category are listed in Table 10. The list includes a number of verbs describing various types of behaviors, e.g. bludanut'/bljadanut' 'lecher, fornicate', dristanut'/dristnut' 'chicken out', dubanut' 'act silly' and rexnut' 'go crazy'. Other verbs denote physical reactions such as dubnut' 'freeze', trepetnut' 'tremble, quiver' and xolonut' 'become colder'. Since the physical reactions involve the body, these verbs are related to bodily acts, but unlike the bodily acts, these physical reactions are not deliberate actions carried out by an agentive subject. Together with optical verbs, which are also not agentive, verbs denoting physical reactions indicate the expansion of the semelfactive aktionsart beyond verbs with agentive subjects. Table 10 furthermore includes several words related to computers, e.g. kopirnut' 'copy (e.g. a computer program), use a copying machine', xaknut' 'hack (a computer program)' and xelpanut' 'help (use the help function in a computer program)'. These words denote deliberate actions carried out by agentive subjects, but they differ from bodily acts in that they are disembodied since they take place in cyberspace. A related word is faksanut' 'send a fax'. Again this is a deliberate action, and although it involves the body (entering a fax number on a keyboard etc.), the transmission of the message does not presuppose moving body parts, so faksanut' is not classified as a bodily act. Words like djubnut', tyrnut' and čerdanut' that all denote stealing are also related to bodily acts, although in modern times theft (e.g. identity theft) does not necessarily involve bodily movement. I have not classified the stealing verbs as bodily acts, since theft is defined in terms of the abstract concept of possession, rather than movement of certain parts of the body. Taken together, the verbs in Table 10 testify to the continued expansion of the semelfactive aktionsart through the verbal lexicon of CSR.

$\begin{array}{llll}\begin{array}{l}\text { ataknut' } \\ \text { barternut' }\end{array} & \begin{array}{l}\text { 'attack' } \\ \text { 'exchange }\end{array} & \begin{array}{l}\text { rabotnut' } \\ \text { reagnut' }\end{array} & \text { 'work' } \\ \text { 'react' } \\ \text { bašljanut' } & \text { 'parter)' } & & \\ \text { bzdnut' } & \text { 'be(come) scared' } & \text { rjuxnut' } & \text { 'go crazy' } \\ \text { bludanut' } & \text { 'lecher, fornicate' } & \text { sortirnut' } & \text { 'sort' } \\ \text { bljadanut' } & \text { 'lecher, fornicate' } & \text { spornut' } & \text { 'quarrel, debate' } \\ \text { draznut' } & \text { 'tease' } & \text { startanut' } & \text { 'start' } \\ \text { dristanut' } & \text { 'chicken out' } & \text { stebanut' } & \text { 'mock' } \\ \text { dristnut' } & \text { 'chicken out' } & \text { stimul'nut' } & \text { 'stimulate' } \\ \text { dubanut' } & \text { 'behave silly' } & \text { trepetnut' } & \text { 'tremble, quiver' } \\ \text { dubnut' } & \text { 'freeze' } & \text { trepyxnut' } & \text { 'flutter' }\end{array}$

${ }^{31}$ Pearson's Chi-squared test with Yates' continuity correction (X-squared $=11.3727, \mathrm{df}=1$ ) gave $\mathrm{p}$ value $=0.0007$. Cramer's V-value equals 0.2 , which indicates a small to moderate effect size. Notice that I have counted verbs with -nu- and -anu- as different lexical items; although the semantic difference between e.g. xvastnut' and xvastanut' is small, the -anu- suffix in general carries expressive or intensifying nuances (Švedova (ed.) 1980: 349). 


\begin{tabular}{|c|c|c|c|}
\hline djubnut' & $\begin{array}{l}\text { 'steal, drink a } \\
\text { shot' }\end{array}$ & tyrnut' & 'steal' \\
\hline zemljanut' & $\begin{array}{l}\text { 'expel from } \\
\text { thieves' }\end{array}$ & faksanut' & 'send a fax' \\
\hline igranut' & 'play' & flirtanut' & 'flirt' \\
\hline kipanut' & 'boil' & forsnut' & 'swank, show off' \\
\hline kon"junkturnut' & $\begin{array}{l}\text { 'behave } \\
\text { opportunistically' }\end{array}$ & xaknut' & $\begin{array}{l}\text { 'hack (a } \\
\text { computer)' }\end{array}$ \\
\hline kopirnut' & 'copy' & xvastanut' & 'brag' \\
\hline koprinut' & 'copy' & xvastnut' & 'brag' \\
\hline korotnut' & 'short circuit' & xelpanut' & 'use help function' \\
\hline kritiknut' & 'criticize' & xolonut' & 'become colder' \\
\hline loxanut' & 'be silly, naïve' & citatnut' & 'quote' \\
\hline pljasanut' & 'dance' & čerdanut' & 'steal' \\
\hline ppksnut' & 'subscribe to' & èkspluatnut' & 'exploit' \\
\hline prestanut' & $\begin{array}{l}\text { 'petrify, stop } \\
\text { doing' }\end{array}$ & & \\
\hline
\end{tabular}

Table 10: Behavior/miscellaneous low-frequent verbs ("occasionalisms") in CSR

\section{Conclusion}

This study has revolved around four questions: What is a semelfactive verb? What doec the OCS text corpus tell us about the early history of the semelfactive aktionsart? Did the semelfactive aktionsart expand in Old Russian? Has the expansion continued in CSR? By way of conclusion, I will summarize my answers to each question.

With regard to the definition of "semelfactive", I have explored four characteristic properties: uniformity, instantaneousness, non-resultativity and single occurrence. While all these properties are well known from the scholarly literature on aspect and aktionsarten in Russian, I have proposed that they define a prototype and that the semelfactive aktionsart is best understood as a radial category organized around this prototype. Instead of asking whether or not a given verb is semelfactive, a more insightful analysis is arrived at if we ask how close or distant a given verb (as used in a given context) is from the prototype defined in terms of the four properties mentioned above.

When it comes to the question about the situation in OCS, we have seen that there is a small group of verbs that meet the criteria of the definition of the semelfactive aktionsart. They are all bodily acts involving volitional actions performed by an agentive subject who moves a body part (mouth or hand) in order to carry out the action. Although the nasal suffix does not have high validity as a cue for the semelfactive actionsart in OCS, there is sufficient evidence to claim the existence of a semelfactive aktionsart in an embryonic stage.

Did the semelfactive aktionsart expand in Old Russian? The data adduced in the present study does not indicate higher cue validity for semelfactive $n u$-verbs, but I have demonstrated that in Old Russian the semelfactive aktionsart is no longer confined to bodily acts, but also comprises auditory verbs and optical verbs, as well 
as verbs of physical movement. I have proposed that these types of verbs form a radial category where the peripheral subcategories (auditory, optical and verbs of physical movement) are connected to the prototypical bodily acts through metonymical relations.

Concerning the situation in CSR, the data presented in this study suggest that the center of gravity is in the process of shifting from bodily acts to auditory verbs. It has also been shown that the semelfactive aktionsart is spreading to verbs beyond the four types attested in Old Russian. This tendency is particularly clear for lowfrequent verbs, but even for high-frequent verbs there is a number of "behavior verbs" among the semelfactives.

In addition to demonstrating that the Russian semelfactive aktionsart has roots far back in the history of the Slavic languages, the present study paves the way for further research on the semelfactive and similar morphological categories. In this study, we have not considered prefixed nu-verbs or $n u$-verbs with the -sja postfix. We have furthermore examined only suffixed semelfactives, but many researchers also regard verbs such as sglupit' 'do one stupid thing' with the prefix sas semelfactives. The question arises as to how such verbs can be integrated in the radial category proposed in the present study, and to what extent this radial category provides a good model for the historical development of $s$-semelfactives, as well as $n u$-verbs with prefixes and/or the -sja postfix. However, while these questions are beyond the scope of the present study and must be left open for future research, the analysis advanced in this study suffices to show that the radial category offers a valuable tool for the diachronic analysis of the semelfactive aktionsart and by implication for the development of other morphological categories over time.

\section{References}

Aitzetmüller, R. (1977) Belegstellenverzeichnis der altkirchenslavischen Verbalformen. Würzburg: U.W. Weiher.

Bates, Elizabeth and Brian MacWhinney (1987) "Competition, variation, and language learning". Brian MacWhinney, ed. Mechanisms of language acquisition. Hillsdale, NJ: Lawrence Erlbaum Associates, 157-194.

Berkov, Valerij P. (2011) Stor russisk-norsk ordbok. Oslo: Kunnskapsforlaget.

Bertinetto, Pier Marco and Anna Lentovskaya (2011) "A diachronic view of the actional/aspectual properties of Russian verbs". Russian Linguistics 36.1: 1-19.

Bybee, Joan (2001) Phonology and Language Use. Cambridge: Cambridge University Press.

Cejtlin, Ralja M., Radoslav Večerka and Èmilija Blagova (1999) Staroslavjanskij slovar'. Moscow: Russkij jazyk.

Croft, William (2006) "On Explaining Metonymy". Cognitive Linguistics 17.3: 317326.

Dickey, Stephen M. (2008) "A prototype account of the development of delimitative po- in Russian". Dagmar Divjak and Agata Kochanska, eds. Cognitive Paths into the Slavic Domain. Berlin: Mouton de Gruyter, 326-371. 
Dickey, Stephen M. and Laura A. Janda (2009) "Xoxotnul, sxitril: The relationship between semelfactives formed with -nu- and $s$ - in Russian", Russian Linguistics, 33.3: 229-248.

Diels, Paul (1961) Altkirchenslavische Grammatik (second ed.), Heidelberg: Carl Winther.

Dmitriev, L. A. (translator) (2005-2011) Zadonščina. Electronic edition by Institut russkoj literatury RAN, available at http://lib.pushkinskijdom.ru/Default.aspx?tabid=4947.

Dmitriev, L. A. and D. S. Lixačev (eds.) (1967) Slovo o polku Igoreve. Leningrad: Sovetskij pisatel'.

Dostál, Antonín (1954) Studie o vidovém systému v staroslověnštině. Prague: Státní pedagogické nakladatelství.

Dressler, Wolfgang U., and Natalia V. Gagarina (1999) "Basic questions in establishing the verb classes of contemporary Russian". L. Fleishman, M. Gasparov, T. Nikolaeva, A. Ospovat, V. Toporov, A. Vigasin, R. Vroon and A. Zaliznjak, eds. Essays in Poetics, Literary History and Linguistics Presented to V. V. Ivanov on the Occasion of his Seventieth Birthday. Moscow: OGI, 754-760.

Eckhoff, Hanne M. (2010) "Where constructions intersect: Old Church Slavonic touch verbs". Unpublished presentation at the 6th International Conference on Construction Grammar (ICCG-6) in Prague, September 3-5, 2010, available at http://www.hf.uio.no/ifikk/english/research/projects/proiel/Activities/proiel/ publications/hanne_praha.pdf.

Evgen'eva, A. P. (ed.) (1999) Malyj akademičeskij slovar'. Moscow: Russkij jazyk.

Goldberg, Adele E. (2006) Constructions at work. Oxford: Oxford University Press.

Grekov, B. D. (ed.) (1940/1967) Pravda Russkaja I: teksty. Moscow and Leningrad: Izdatel'stvo akademii nauk SSSR. (Reprinted in 1967. Düsseldorf: Brücken-Verlag and The Hague: Europe Printing.)

Isačenko, Aleksander I. (1960) Grammatičeskij stroj russkogo jazyka v sopostavlenii so slovackim. Bratislava: Izdatel'stvo slovackoj akademii nauk.

Isačenko, Aleksander I. (1958/1982) Die russische Sprache der Gegenwart: Formenlehre. Munich: Niemeyer.

King, Bruce M. and Edward W. Minium (2008) Statistical reasoning in the behavioral sciences. Hoboken, NJ: John Wiley \& Sons.

Kloss, B. M. (1980) Nikonovskij svod i russkie letopisi XVI-XVII vekov. Moscow: Nauka.

Kuznetsova, Julia and Anastasia Makarova (2012) "Distribution of two semelfactives in Russian: -nu- and -anu-". Oslo Studies in Language 4(1): 155-176.

Lakoff, George (1987) Women, Fire, and Dangerous Things. Chicago: The University of Chicago Press.

Lunt, Horace (1969) Old Church Slavonic Glossary (corrected reprint). Department of Slavic Languages and Literatures: Harvard University.

Lunt, Horace (2001) Old Church Slavonic Grammar (seventh ed.). Mouton: Berlin and New York

Makarova, Anastasia and Laura A. Janda (2009) "Do It Once: A Case Study of the Russian -nu-Semelfactives". Scando-Slavica 55: 78-99. 
Maslov, Jurij M. (1961/2004) “Rol’ tak nazyvaemoj perfektivacii i imperfektivacii v processe vozniknovenija slavjanskogo glagol'nogo vida". Reprinted in Izbrannye trudy. Moscow: Jazyki slavjanskoj kul'tury: 445-476.

Nabokov, Vladimir (translator) (1960) The song of Igor's campaign. Translated from Old Russian by Vladimir Nabokov. New York: Vintage books.

Nesset, Tore (2012) "One or several categories? The Old Church Slavonic no-verbs and linguistic profiling”. Russian Linguistics 36.3: 285-303.

Obrebska-Jablonska, Antonina and Irena Dulewicz (1968) Indeks a tergo do Materialow do slownika jezyka staroruskiego I.I. Srezniewskiego. Warszawa: PWN.

Ostrowski, Donald (ed.) (2003) The Pověst' vremennykh lět: An Interlinear Collation and Paradosis. Volume 1. Cambridge, Mass.: Harvard University Press.

Ožegov, Sergej I. and Natalija Ju. Švedova (2001) Slovar' russkogo jazyka. Moscow: Russkij jazyk.

Panther, Klaus-Uwe and Linda Thornburg (1999) "The Potentiality for Actuality Metonymy in English and Hungarian". Klaus-Uwe Panther, ed. Metonymy in Language and Thought. Amsterdam/Philadelphia: John Benjamins, 333-360.

Peirsman, Yves and Dirk Geeraerts (2006) "Metonymy as a Prototypical Category". Cognitive Linguistics 17.3: 269-316.

Ponyrko, N. V. (ed.) (1983) Povesti Drevnej Rusi. Leningrad: Lenizdat.

Radden, Günther and Zoltan Kövecses (1999) "Towards a Theory of Metonymy". Klaus-Uwe Panther, ed. Metonymy in Language and Thought. Amsterdam/Philadelphia: John Benjamins, 17-60.

Sadnik, Linda and Rudolf Aitzetmüller (1955) Handwörterbuch zu den altkirchenslavischen Texten. The Hague: Mouton.

Šatunovskij, Il'ja Borisovič (2009) Problemy russkogo vida. Moscow: jazyki slavjanskix kul'tur.

Severjanov, Sergej (ed.) (1904/1956) Codex Suprasliensis. Reprinted Graz 1956.

Sigalov, Pavel (1963) “Glagoly s suffiksom -anu-- (--onu--) v russkom jazyke”. Učenye zapiski Leningradskogo Ordena Lenina Gosudarstvennogo Universiteta Imeni A. A. Ždanova: 64-79.

Silina, V. B. (1982) “Istorija kategorii glagol'nogo vida”. R. I. Avanesov, ed. Ictoričeskaja grammatika russkogo jazyka. Morfologija: Glagol. Moscow: Nauka, 158-279.

Slovar' russkogo jazyka XI-XVII vv. (1975-). Moscow: Nauka.

Smith, Carlota S. (1997) The Parameter of Aspect. Dordrecht: Kluwer Academic Publications.

Sreznevskij, I. I. (1893-1906) Materialy dlja slovarja drevnerusskogo jazyka po pis'mennym pamjatnikam. St Petersburg: Tipografija imperatorskoj akademii nauk.

Švedova, Natalija Ju. (ed.) (1980) Russkaja grammatika I. Moscow: Nauka.

Švedova, Natalija Ju. And Sergej I. Ožegov (2001) Tolkovyj slovar' russkogo jazyka. Moscow: Russkij jazyk.

Sverdlov, M. B. (2006-2011) “Russkaja Pravda (prostrannaja redakcija). Vstuplenie $\mathrm{k}$ tekstu". Electronic edition by Institut russkoj literatury RAN, available at http://lib.pushkinskijdom.ru/Default.aspx?tabid=4947. 
Ušakov, Dmitrij N. (1935-40/2008) Bol'šoj tolkovyj slovar' sovremennogo russkogo jazyka. Moscow: Alta Print.

Zaliznjak, Andrej A. (2004) Drevnenovgorodskij dialect. Moscow: Jazyki slavjanskoj kul'tury.

Zaliznjak, Andrej A. (2007) "Slovo o polku Igoreve": vzgljad lingvista. Moscow: Rossijskaja akademija nauk.

Zaliznjak, Anna A. and Aleksej Šmelev (2000) Vvedenie v russkuju aspektologiju. Moscow: Jazyki russkoj kul'tury. 